\title{
A novel tropopause-related climatology of ozone profiles
}

\author{
V. F. Sofieva ${ }^{1}$, J. Tamminen ${ }^{1}$, E. Kyrölä ${ }^{1}$, T. Mielonen ${ }^{2,3}$, P. Veefkind ${ }^{3,4}$, B. Hassler ${ }^{5,6}$, and G.E. Bodeker ${ }^{7}$ \\ ${ }^{1}$ Finnish Meteorological Institute, Helsinki, Finland \\ ${ }^{2}$ Finnish Meteorological Institute, Kuopio, Finland \\ ${ }^{3}$ Royal Netherlands Meteorological Institute (KNMI), De Bilt, the Netherlands \\ ${ }^{4}$ Delft University of Technology, Faculty of Civil Engineering and Geosciences Department of Geoscience and Remote \\ Sensing, Delft, the Netherlands \\ ${ }^{5}$ CIRES, University of Colorado, Boulder, CO, USA \\ ${ }^{6}$ NOAA, ESRL, Chemical Sciences Division, Boulder, CO, USA \\ ${ }^{7}$ Bodeker Scientific, Alexandra, Central Otago, New Zealand
}

Correspondence to: V. F. Sofieva (viktoria.sofieva@fmi.fi)

Received: 10 July 2013 - Published in Atmos. Chem. Phys. Discuss.: 16 August 2013

Revised: 19 November 2013 - Accepted: 25 November 2013 - Published: 9 January 2014

\begin{abstract}
A new ozone climatology, based on ozonesonde and satellite measurements, spanning the altitude region between the earth's surface and $\sim 60 \mathrm{~km}$ is presented $\left(\mathrm{TpO}_{3}\right.$ climatology). This climatology is novel in that the ozone profiles are categorized according to calendar month, latitude and local tropopause heights. Compared to the standard latitude-month categorization, this presentation improves the representativeness of the ozone climatology in the upper troposphere and the lower stratosphere (UTLS). The probability distribution of tropopause heights in each latitude-month bin provides additional climatological information and allows transforming/comparing the $\mathrm{TpO}_{3}$ climatology to a standard climatology of zonal mean ozone profiles. The $\mathrm{TpO}_{3}$ climatology is based on high-vertical-resolution measurements of ozone from the satellite-based Stratospheric Aerosol and Gas Experiment II (in 1984 to 2005) and from balloon-borne ozonesondes from 1980 to 2006.

The main benefits of the $\mathrm{TpO}_{3}$ climatology are reduced standard deviations on climatological ozone profiles in the UTLS, partial characterization of longitudinal variability, and characterization of ozone profiles in the presence of double tropopauses.

The first successful application of the $\mathrm{TpO}_{3}$ climatology as a priori in ozone profile retrievals from Ozone Monitoring Instrument on board the Earth Observing System (EOS) Aura satellite shows an improvement of ozone precision in UTLS of up to $10 \%$ compared with the use of conventional climatologies.
\end{abstract}

In addition to being advantageous for use as a priori in satellite retrieval algorithms, the $\mathrm{TpO}_{3}$ climatology might be also useful for validating the representation of ozone in climate model simulations.

\section{Introduction}

The tropopause is the boundary between the troposphere and the stratosphere, two atmospheric layers that have dramatically different thermal stratification, static stability, and chemical composition. The tropopause is often considered as a transition region (or so-called mixing layer) between the upper troposphere and lower stratosphere rather than a barrier at a single altitude (Hoor et al., 2002; Kunz et al., 2009; Pan et al., 2004), whose thickness is not uniform over the globe (Feng et al., 2012). The location of the tropopause can be defined in different ways (see reviews of Gettelman et al., 2011, and Hoerling et al., 1991, and references therein). The most used definitions are a thermal tropopause based on temperature lapse-rate criteria and a dynamic tropopause based on potential vorticity criteria. While the definition of the lapse-rate/thermal tropopause (WMO, 1957) has remained unchanged for more than a half of century, the thresholds on potential vorticity gradients used in the dynamical tropopause definition are still a matter of debate (Gettelman et al., 2011, and references therein). The thermal tropopause determined by the WMO definition is often multivalued, even 
in the climatology. The morphology of double and multiple tropopauses is the subject of active recent research (Añel et al., 2008; Peevey et al., 2012; Randel et al., 2007).

Ozone abundances in the stratosphere are more than an order of magnitude greater than in the troposphere. Thus variations in the tropopause height are mostly responsible for large variability in climatological ozone values in the upper troposphere and lower stratosphere (UTLS) in pressurelevel-/sea-level-referenced climatologies (e.g., Fortuin and Kelder, 1998; McPeters et al., 2007). The tropopausereferenced ozone climatologies of e.g. Logan (1999), Wang et al. (2006), Thouret et al. (2006), Wei et al. (2010), Tilmes et al. (2010, 2012), and Bak et al. (2013) are characterized by a reduced variability in the UTLS compared to sea-levelreferenced climatologies.

The tropopause-referenced climatologies better reflect the steep vertical gradient in ozone across the tropopause and a smaller ozone variance resulting from day-to-day meteorological variability in the UTLS region. However, there are two main problems associated with the tropopausereferenced representation of an ozone climatology. First, ozone profiles cannot be considered as simply statically vertically shifted with respect to each other as a result of differences in their respective tropopause heights. For example, a springtime longitudinal asymmetry in the ozone distribution over Antarctica, which is induced by quasi-stationary planetary wave number 1, is a climatological feature (Evtushevsky et al., 2008; Grytsai et al., 2005, 2007; Ialongo et al., 2012). Because of chemically induced ozone destruction, profiles measured inside and outside the Antarctic polar vortex are very different. Since the location of the tropopause over Antarctica is influenced by the temperature of the lower stratosphere, low ozone abundances in some regions are associated with a high tropopause and vice versa (examples of ozone and temperature profiles are given in Evtushevsky et al., 2008). Second, double tropopauses are a rather common feature in the extratropics (Pan et al., 2009; Peevey et al., 2012), where UTLS ozone displays a characteristic vertical structure (Pan et al., 2004; Randel et al., 2007).

A tropopause-sensitive ozone climatology is better suited for use as a priori in ozone profile retrievals from satellite nadir-looking instruments. For example, Wei et al. (2010) have demonstrated a significant improvement in the retrievals from the Atmospheric Infrared Sounder (AIRS) when using a tropopause-referenced ozone profile climatology as a priori. The same was true for the Ozone Monitoring Instrument (OMI) (Bak et al., 2013). Currently, most retrieval algorithms use the sea-level-referenced ozone climatology of McPeters et al. (2007) (hereafter referred to as the LLM climatology as in the original paper), which is based on ozonesonde data and satellite-based measurements from the Stratospheric Aerosol and Gas Experiment II (SAGE-II) and the Microwave Limb Sounder (MLS) on board the Upper Atmosphere Research Satellite (UARS).
In this study, a new way of generating ozone climatology is introduced: more than a single mean ozone profile is derived for each latitude zone/month. Rather, each mean ozone profile is derived from all the profiles in that latitude-month bin, which have a certain tropopause height (i.e., the profiles are further disaggregated by tropopause height). The ozone climatology created in such a way is sensitive to the variability induced by changes in tropopause height. It has therefore a better characterization of the vertical distribution of ozone across the UTLS and of the ozone structure in cases of double tropopauses.

The paper is organized as follows. Section 2 briefly describes the data used for the analysis. Section 3 presents the data processing and the tropopause statistics derived from the ozonesonde and SAGE-II/NCEP data. Section 4 describes the method for combining/merging climatologies from the ozonesonde and satellite measurements. Section 5 describes the ozone morphology in the new tropopause-related climatology and presents comparisons with other ozone climatologies. The advantages of using the new climatology in satellite retrievals are demonstrated in Sect. 6. A discussion and summary conclude the paper.

\section{Data}

For reliable characterization of the vertical distribution of ozone in the UTLS, accurate and high-vertical-resolution data are required. To create a linked ozone-tropopause climatology (hereafter referred to as the $\mathrm{TpO}_{3}$ climatology), ozone profiles from ozonesondes and the SAGE-II satellite instrument were used.

\subsection{Ozonesondes}

Ozonesonde measurements for the period 1980 to 2006 were extracted from the Binary Data Base of Profiles (BDBP) (Hassler et al., 2008). The list of ozone stations can be found in Table A1 in Hassler et al. (2008). The BDBP includes more ozonesonde data than were used in the creation of the LLM climatology (35928 ozone profiles from 136 stations used in our study compared to 23400 ozone profiles from 36 stations used for the LLM climatology). However, the longitudinal coverage by ozonesonde measurements remains highly non-uniform. Both the ozone and temperature profiles in BDBP are interpolated onto a $1 \mathrm{~km}$ grid. Despite the degraded vertical resolution compared to the original ozonesonde data $(\sim 80-100 \mathrm{~m}$ for ozone and $10-50 \mathrm{~m}$ for temperature), this resolution is sufficient for accurate determination of the position of the tropopause based on the WMO definition (Homeyer et al., 2010; Reichler et al., 2003, see also details in Sect. 3). Furthermore, it is important to use smoothed radiosonde profiles for tropopause detection, in order to avoid errors in lapse rate calculations caused by measurement noise, as pointed by Homeyer et al. (2010). In 

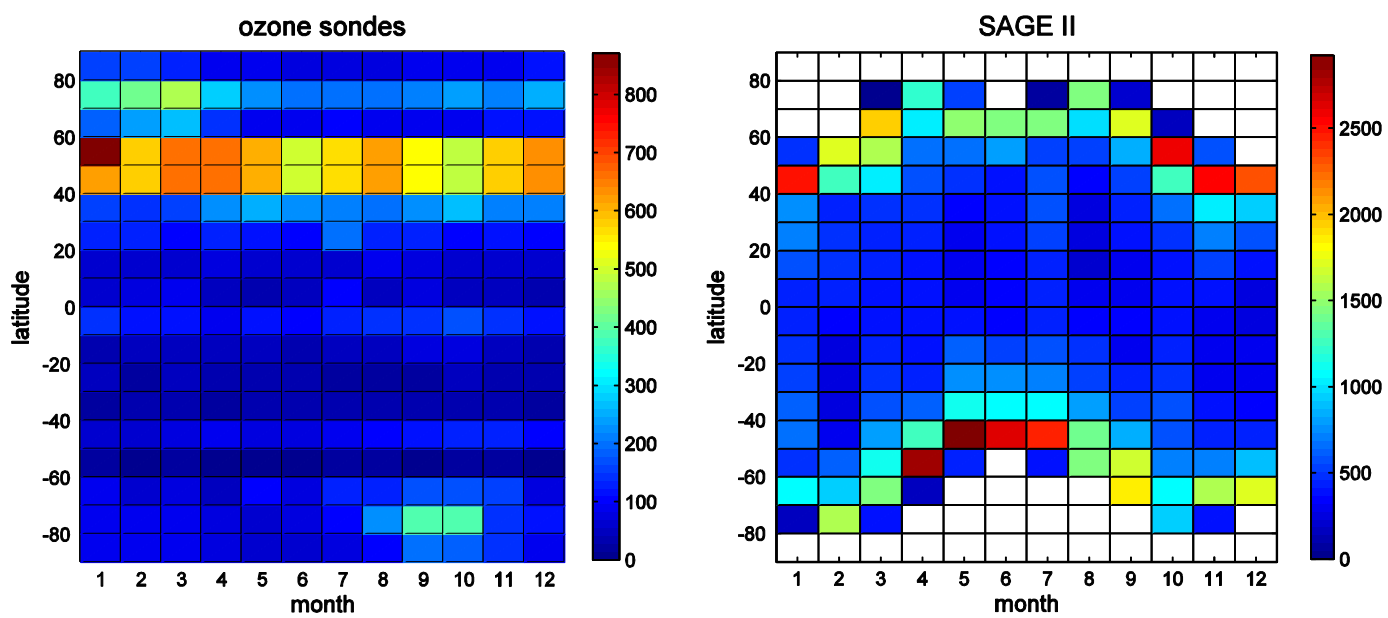

Fig. 1. Number of measurements in $10^{\circ}$ latitude zones and in each month. Left: ozonesondes from the BDBP; right: SAGE II.

this study, the ozone profile statistics is presented for each tropopause height in $1 \mathrm{~km}$ bins consistent with the vertical resolution of the data extracted from the BDBP. The number of available ozonesonde data is highly location- and season-dependent (Fig. 1, left). Data availability is largest over Northern Hemisphere (NH) mid-latitudes. In polar regions, more data are available in winter and spring.

\subsection{SAGE-II}

SAGE-II is a solar occultation instrument on board Earth Radiation Budget Satellite (ERBS), which operated between 1984 and 2005. Version 6.2 SAGE-II data (Wang et al., 2006; http://www-sage2.larc.nasa.gov/Version6-2Data. html) are used in our study. These data are provided on $0.5 \mathrm{~km}$ altitude grid. SAGE-II data have good vertical resolution, a very good precision in the stratosphere (estimated precision provided in the data files is $0.5-3 \%$; Wang et al., 2002), and they have a very small bias with respect to ozonesonde data (Wang et al., 2002). There is a bias between sunset and sunrise measurements in the upper stratosphere increasing from $\sim 2 \%$ at $35 \mathrm{~km}$ up to $\sim 10 \%$ at $50 \mathrm{~km}$ (e.g., Wang et al., 1996; Kyrölä et al., 2013), which can be partially explained by ozone diurnal variations (Kyrölä et al., 2013; Sakazaki et al., 2013). Here, the original sunset and sunrise SAGE-II profiles were used such that the climatological profiles represent the average of sunset and sunrise data.

The temperature profiles, which are included in the SAGEII data set for each occultation, are taken from National Centers for Environmental Prediction (NCEP) reanalysis data. The temperature profiles are presented on the same $0.5 \mathrm{~km}$ grid as ozone profiles; they have the vertical resolution of $\sim 1.5-2 \mathrm{~km}$ in UTLS. The data screening as described in Hassler et al. (2008) was applied to the data. In addition, all data affected by the Mt. Pinatubo volcanic eruption were excluded. The SAGE-II data coverage is displayed in the right- hand panel of Fig. 1. The latitudes poleward of $80^{\circ}$, as well as the polar night regions, are not sampled by SAGE-II.

\section{Data processing and the statistics of tropopauses}

In this analysis, the World Meteorological Organization (WMO) definition of the lapse-rate tropopause has been used (WMO, 1957). Namely, the (first) tropopause is defined as the lowest level above the $500 \mathrm{hPa}$ level where the lapse rate decreases to $2 \mathrm{~K} \mathrm{~km}^{-1}$ or less, provided also the average lapse rate between this level and all higher levels within $2 \mathrm{~km}$ does not exceed $2 \mathrm{~K} \mathrm{~km}^{-1}$. When above the first tropopause the average lapse rate between any level and all higher levels within $1 \mathrm{~km}$ exceeds $3 \mathrm{~K} \mathrm{~km}^{-1}$, then a second tropopause is identified in the same way as the first tropopause. This definition is clear and simple in implementation and, as a result, has been used in many studies (Gettelman et al., 2011, and references therein). To account for the lower vertical resolution of the NCEP temperature profiles provided with SAGEII data, a lapse rate of $2 \mathrm{~K} \mathrm{~km}^{-1}$ is used instead of $3 \mathrm{~K} \mathrm{~km}^{-1}$ in the original WMO definition, as recommended by Randel et al. (2007).

The tropopause was detected for each ozonesonde and SAGE-II profile. Then for each $10^{\circ}$ latitudinal bin, and for each month, the ozone profiles were grouped according to tropopause height in $1 \mathrm{~km}$ intervals, and the mean ozone profile and variability (characterized by the standard deviation of the distribution) were computed. This analysis was performed separately for the ozonesonde data and for the SAGE-II data. As a result, for each latitude-month bin, several climatological ozone profiles are created, each corresponding to a certain tropopause height. As part of the analysis, the distribution of tropopause height in each latitudemonth bin (which can be considered as a climatology of tropopause heights) is also derived. This experimental probability distributions of tropopause heights (i.e., the percentage 

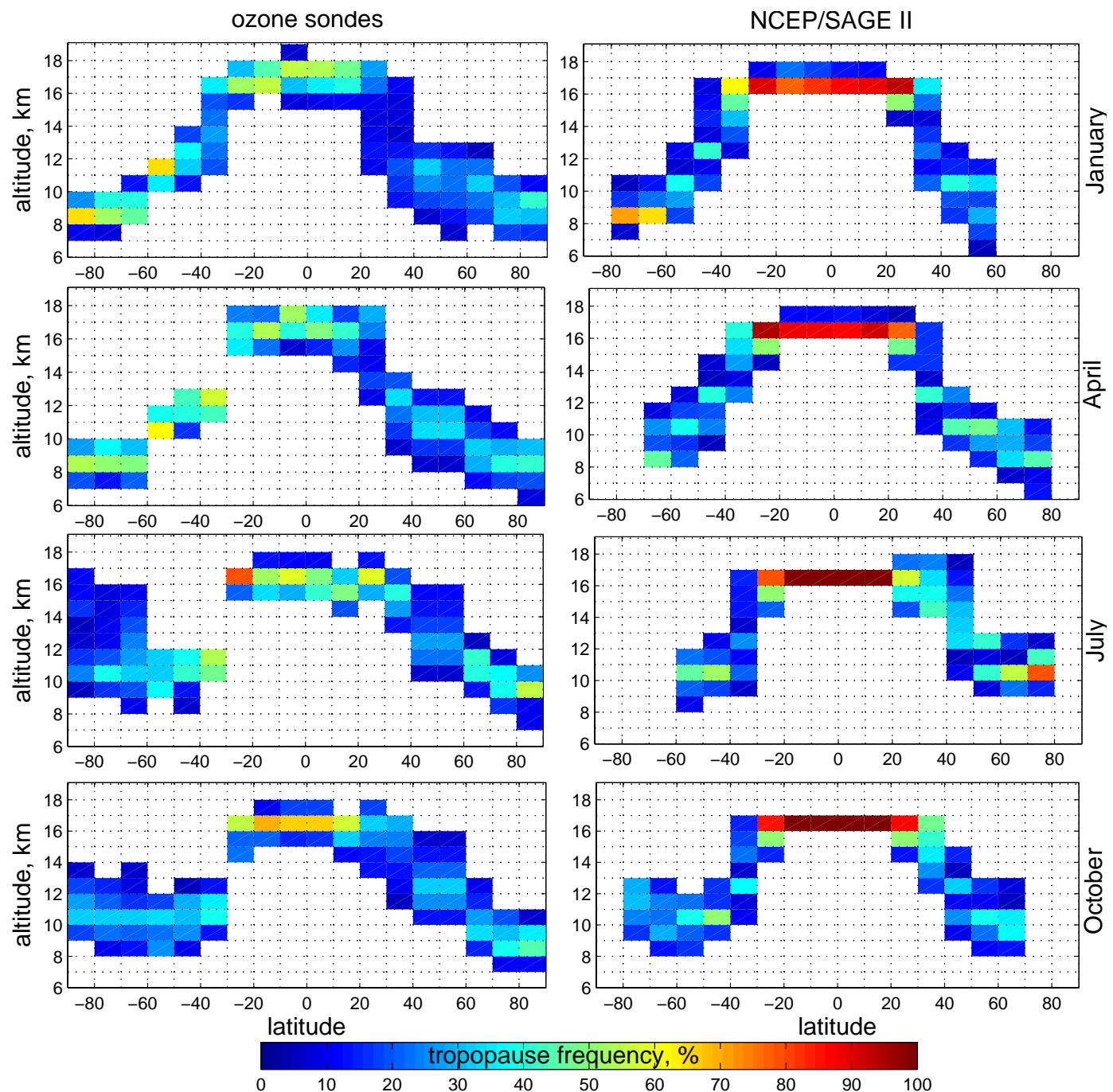

Fig. 2. Distribution of tropopause height and frequency of occurrence (in \%), for January, April, July and October. Left: ozonesondes, right: NCEP/SAGE II.

of observations having tropopause heights in each $1 \mathrm{~km}$ bin) are stored thereby giving additional information that allows downgrading/comparing the ozone-tropopause climatology to the standard climatology of zonal mean ozone profiles. Below we discuss the derived statistics of tropopauses.

The histograms of tropopause heights (single tropopauses) for different latitudes and seasons are shown in Fig. 2, for ozonesondes (left column) and NCEP temperature profiles at SAGE-II occultation locations (right column). While the tropopause height histograms determined from the ozonesonde temperature profiles are in broad agreement with those determined from the NCEP/SAGE-II profiles, the distributions tend to cover a broader altitude range in the ozonesonde data. This might be a consequence of different temporal and spatial sampling of SAGE-II and ozonesonde data (as discussed, e.g., by Tilmes et al., 2012), or different vertical resolution of ozonesonde and NCEP tempera- ture profiles. The quality of tropopause data from meteorological (low-resolution) reanalyses has been studied previously (e.g., Borsche et al., 2007; Randel et al., 2000, 2007). The broad agreement between the NCEP/SAGE-II and radiosonde tropopause height distributions indicates that the tropopause height can be determined from NCEP data sufficiently accurately for our application (note that we group the observed tropopause heights into $1 \mathrm{~km}$ intervals).

The percentages of double-tropopause occurrence for each latitudinal bin and month are shown in Fig. 3, for ozonesondes and NCEP temperature profiles at SAGE-II occultation locations. Overall, a good agreement between these two data sets is observed, confirming the appropriateness of modifying the original WMO definition for processing low-verticalresolution data suggested by Randel et al. (2007). Double tropopauses are frequent in the extratropics in winter and spring, especially in the Northern Hemisphere, as reported 

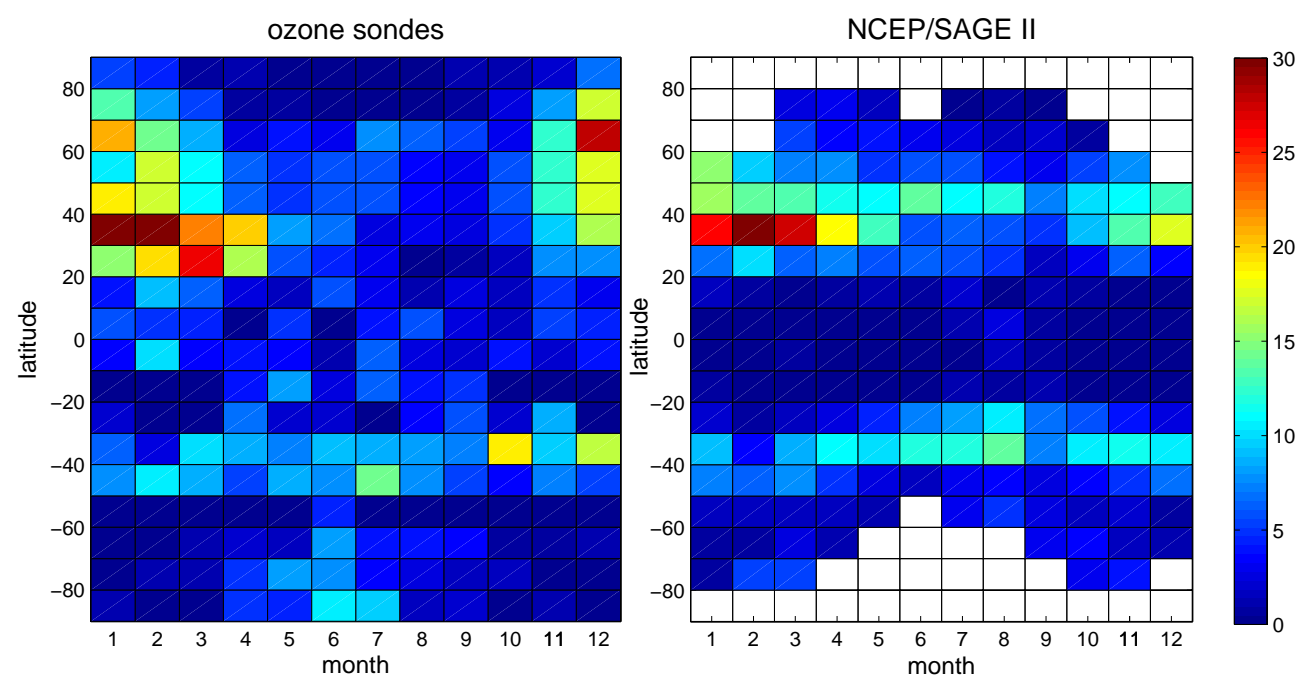

Fig. 3. Percentage of double-tropopause occurrence in ozonesonde profiles and in the NCEP/SAGE II data.

in Añel et al. (2008), Peevey et al. (2012), and Randel et al. (2007). This double-tropopause structure may be associated with stratosphere-troposphere exchange (Pan et al., 2009). In the ozonesonde data, a large percentage of double tropopause is observed in winter at NH high latitudes (which is again in agreement with Randel et al., 2007). The percentage of double-tropopause occurrence is slightly smaller in NCEP-SAGE-II data than in ozonesonde data, which might be attributed to different vertical resolution and/or different spatiotemporal sampling.

The ozone profile characterization in double-tropopause conditions is performed only for locations and months where and when double-tropopause occurrence exceeds $20 \%$. First, the histogram of the first tropopause height was computed using $1 \mathrm{~km}$ altitude bins, and the representative cases (with more than five measurements) were selected. Then, for each bin of the first tropopause, the histogram for the second tropopause height was computed first using $1 \mathrm{~km}$ altitude bins, and then, if no bins with more than five measurements are found, $2 \mathrm{~km}$ bins are used. Finally, the representative cases of the first and second tropopause altitudes are selected, and ozone profiles are averaged for these cases. The examples of double-tropopause statistics are shown in Fig. 4. Some discrepancy between the statistics of double tropopauses calculated using the ozonesonde and the NCEP data is observed. In addition to the reasons mentioned above (different sampling and vertical resolutions), smaller data subsamples corresponding to double tropopauses might contribute to the observed discrepancy.

\section{Creating the $\mathrm{TpO}_{3}$ climatology}

Ozone climatologies incorporating information about tropopause height, which were created separately using
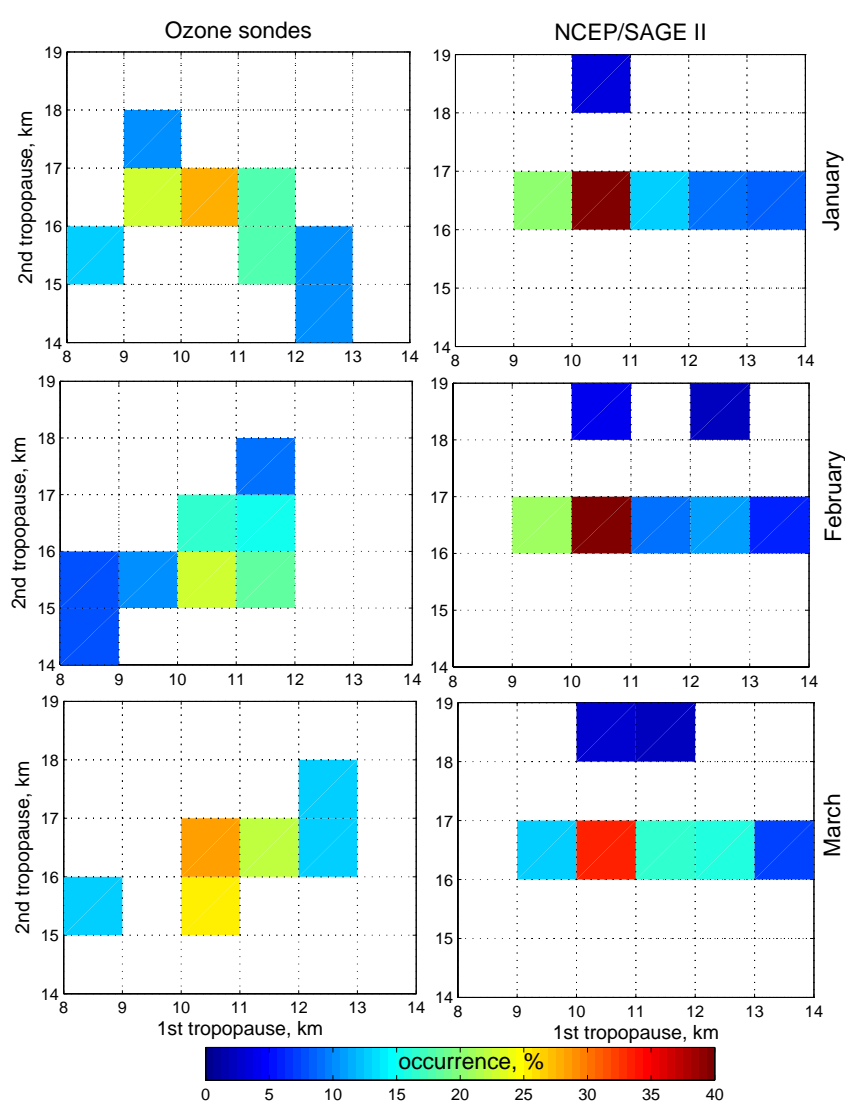

Fig. 4. Statistics of double tropopauses at $30^{\circ}-40^{\circ} \mathrm{N}$ in JanuaryMarch, as obtained from the temperature measurements taken as part of ozonesonde flights (left) and the NCEP reanalysis at the locations of the SAGE-II measurements. 


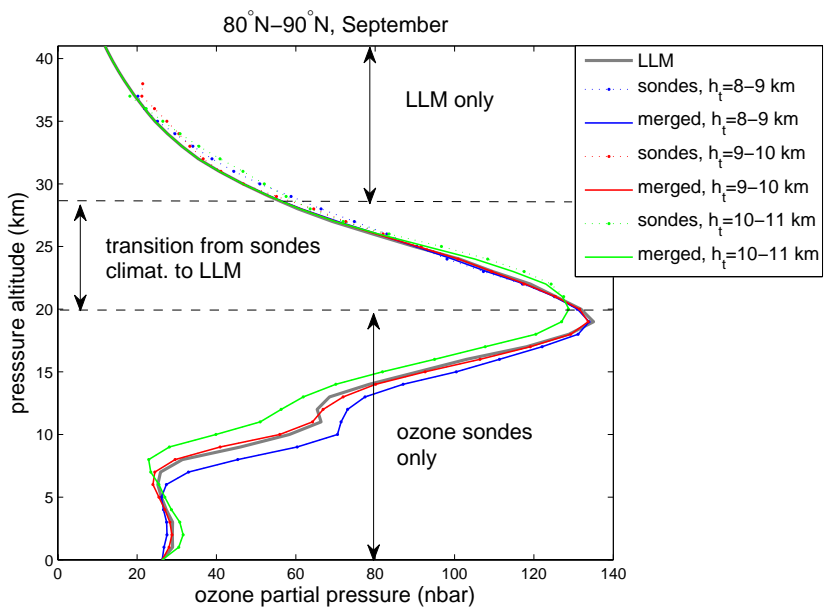

Fig. 5. Illustration of data merging when SAGE-II data are not available. A smooth transition from the ozonesonde climatology to the LLM climatology is performed using the altitude interval $20-28 \mathrm{~km}$. In this and subsequent figures, ozone partial pressure is shown for a better visualization. Note that in $\mathrm{TpO}_{3}$ climatology files, ozone mixing ratio is presented.

ozonesonde and SAGE-II data, are merged into one interrelated ozone and tropopause height climatology covering the altitude range from the earth's surface up to $60 \mathrm{~km}$. In this section, we describe the method used for merging the ozonesonde and satellite climatologies. Depending on availability of SAGE-II data, different approaches are used.

\subsection{Cases when SAGE-II data are not available}

For the locations and months when SAGE-II data are not available, a linear transition of climatological ozonesonde profiles to the LLM climatology using the $20-28 \mathrm{~km}$ altitude interval is applied. Since the LLM climatology represents ozone mixing ratios on a pressure altitude grid (McPeters et al., 2007), the ozonesonde profiles are also presented on such a grid using the pressure data from the corresponding radiosonde. The transformation to pressure altitude $z$ is straightforward using the hydrostatic equation in the standard atmosphere (McPeters et al., 2007): $z=16 \log _{10}\left(P_{0} / P\right)$, where $P_{0}=1013 \mathrm{hPa}$ is the standard pressure and $P$ is pressure in $\mathrm{hPa}$ (the standard form of this relation is $P=$ $P_{0} e^{-z / H}$ with the scale height $\left.H \approx 7 \mathrm{~km}\right)$. However, the analysis of tropopauses was performed using geometric altitudes. Since the pressure altitude and geometric altitude do not differ much in the UTLS (the difference is less than $1 \mathrm{~km}$ ), and because the tropopause is binned in $1 \mathrm{~km}$ intervals, this transformation does not result in any considerable inaccuracy.

The smooth transition from ozonesondes to LLM is performed in the same way as it is done in creating the LLM climatology (McPeters et al., 2007): the weighting of the ozonesonde profile decreases linearly from $100 \%$ at $20 \mathrm{~km}$ to $0 \%$ at $28 \mathrm{~km}$. The transition of the standard deviations is transformed in the same way as the ozone mixing ratios. Figure 5 illustrates the data merging when SAGE-II data are not available, using the data between $80^{\circ} \mathrm{N}$ and $90^{\circ} \mathrm{N}$ in September as an example. For better visualization, profiles of ozone partial pressure are presented (this representation is used also in subsequent figures). The altitude range $20-28 \mathrm{~km}$, where the linear transition from ozonesonde climatological profiles to LLM profiles is performed, is indicated in this figure.

\subsection{Cases when SAGE-II data are available}

Since satellite data have good spatial coverage, it is advantageous to use them over the widest possible altitude range. As mentioned above, SAGE-II data have a very good precision in the stratosphere and a very small bias with respect to ozonesonde data practically down to the tropopause (Wang et al., 2002). However, in the troposphere SAGE-II data are systematically biased low $(\sim 30 \%)$ and exhibit lower precision than in the stratosphere data (Wang et al., 2002, 2006). Therefore SAGE-II data have only been used at and above the tropopause.

\subsubsection{Single tropopause}

For each $10^{\circ}$ latitude zone used in the analyses, there are tropopause heights that are present in both ozonesonde and SAGE-II/NCEP climatologies, but there might also be some tropopause heights that are presented only in one of the data sets (ozonesonde or SAGE-II). Where data from one source are missing, a transition to a climatological profile, either at lower or upper altitudes, is needed. Since such a transition to LLM (or, more generally, to any monthly mean) may induce erroneous profiles (this is especially relevant for polar Southern Hemisphere in winter and spring), only those tropopause heights are used that are available in both SAGEII and ozonesonde climatologies.

Ozonesonde data are used below the altitude $h_{0}=\max$ $\left(h_{t}, 10 \mathrm{~km}\right)$, where $h_{t}$ is the tropopause height. A merging of ozonesonde and SAGE-II profiles is performed at altitudes from $h_{0}$ to $28 \mathrm{~km}$ as described below, with a smooth transition to SAGE-II data over the altitude range $20-28 \mathrm{~km}$. At altitudes from $h_{0}$ to $28 \mathrm{~km}$, the merged sonde-SAGE-II ozone profile is calculated as

$\bar{\rho}=\frac{N_{\mathrm{so}} \bar{\rho}_{\mathrm{So}}+N_{\mathrm{SA}} \bar{\rho}_{\mathrm{SA}}}{N_{\mathrm{So}}+N_{\mathrm{SA}}}$,

where $\bar{\rho}_{\text {So }}$ and $\bar{\rho}_{\text {SA }}$ are mean ozone profiles calculated using ozonesonde and SAGE-II data, respectively, and $N_{\text {so }}$ and $N_{\mathrm{SA}}$ are the corresponding number of ozonesonde and SAGE-II measurements (corresponding to a particular tropopause height $h_{t}$ ). The estimate $\bar{\rho}$ presents the mean over all measurements. The usual sample mean is intentionally calculated without consideration of any predicted measurement uncertainty for weighting purposes, since measurement uncertainties can depend on geolocation or/and the atmospheric state and thus could bias the mean. 

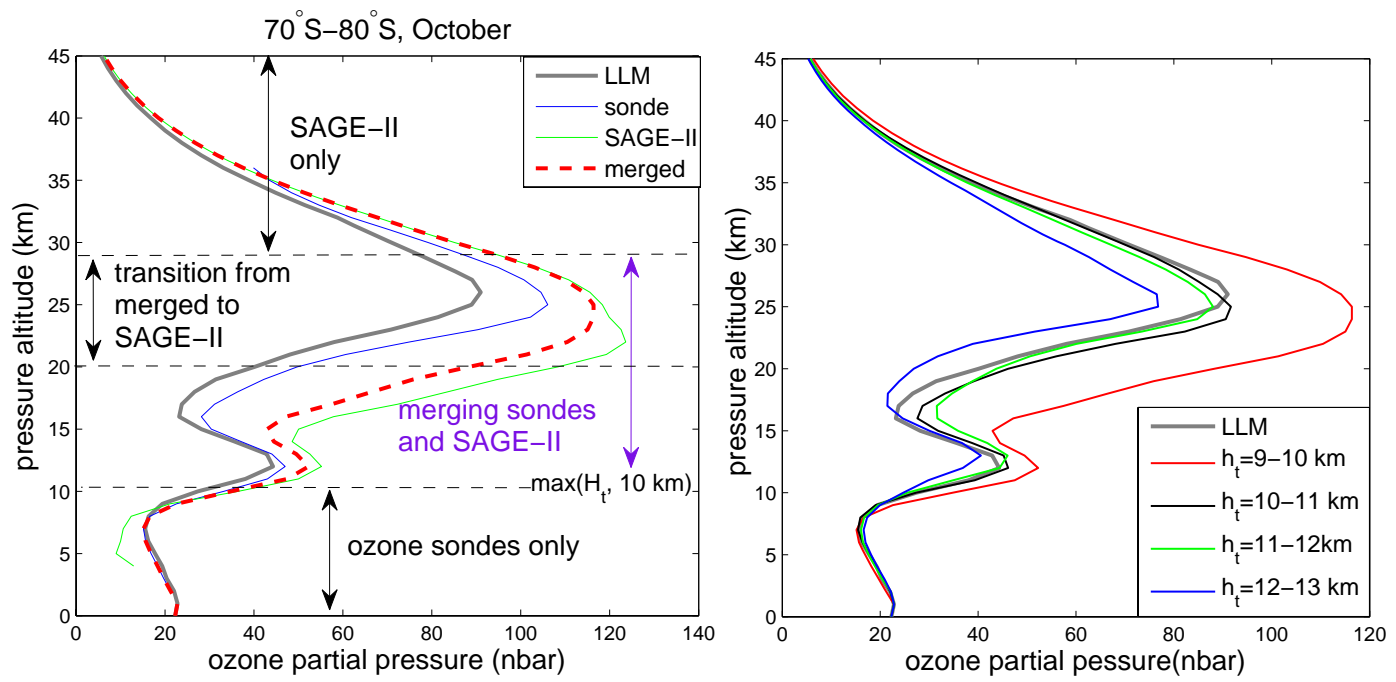

Fig. 6. Illustration of merging sonde and SAGE-II data based on data in October at $70-80^{\circ} \mathrm{S}$. Left: illustration of merging for one of the tropopause heights, which is $9-10 \mathrm{~km}$; altitude ranges for merging sonde and SAGE-II data and for linear transition to SAGE-II data are highlighted. In this example, $N_{\text {so }}=90$ and $N_{\mathrm{SA}}=160$. LLM profile is presented for comparison. Right: merged climatological profiles for different tropopause heights and the LLM profiles for this latitude bin.

Denoting $v_{\mathrm{so}}$ and $v_{\mathrm{SA}}$ the variability (rms) in ozonesonde and SAGE-II data sets, the resulting (merged) variability can be written as

$v^{2}=\frac{N_{\mathrm{so}} v_{\mathrm{So}}^{2}+N_{\mathrm{SA}} v_{\mathrm{SA}}^{2}}{N_{\mathrm{so}}+N_{\mathrm{SA}}}+\frac{N_{\mathrm{So}} N_{\mathrm{SA}}\left(\bar{\rho}_{\mathrm{So}}-\bar{\rho}_{\mathrm{SA}}\right)^{2}}{\left(N_{\mathrm{so}}+N_{\mathrm{SA}}\right)^{2}}$.

If $N_{\mathrm{so}}=0$ or $N_{\mathrm{SA}}=0$, the variability coincides with the variability of the present data set. In case $\bar{\rho}_{\mathrm{SO}}=\bar{\rho}_{\mathrm{SA}}$, the resulting variability is averaged in the same way as the mean profiles.

The transition from $\bar{\rho}$ to $\bar{\rho}_{\text {so }}$ at lower altitudes is performed using a fast three-point transition: the value $1 / 2\left(\bar{\rho}_{\text {so }}+\bar{\rho}\right)$ is taken at the altitude $h_{0}, \bar{\rho}$ above this altitude, and $\bar{\rho}_{\text {so }}$ below.

The probability distribution of tropopause heights is recalculated using the tropopause height bins that are present in both satellite and ozonesonde measurements.

The merging procedure is illustrated in Fig. 6 (left), which shows the original sonde and SAGE-II profiles and the merged profile for one selected tropopause height in October between $70^{\circ} \mathrm{S}$ and $80^{\circ} \mathrm{S}$. In this example, the SAGE-II and ozonesonde profiles, corresponding to the tropopause height $9-10 \mathrm{~km}$, differ significantly. This situation is rather exceptional, and it is purposely selected for visualization clarity. Usually, ozonesonde and SAGE-II profiles are much closer to each other. Final merged ozone profiles for all tropopause height categories at this location, for October, are shown in the right-hand panel of Fig. 6. Figure 6 highlights why the availability of both ozonesonde and satellite data is necessary: the replacement of missing data by the monthly mean profile would result in an erroneous profile associated with a certain tropopause height. Figure 6 (left) indicates the altitude ranges over which the merging of sonde and SAGE-II data occurs (from $h_{0}$ to $28 \mathrm{~km}$ ) and where the linear transition

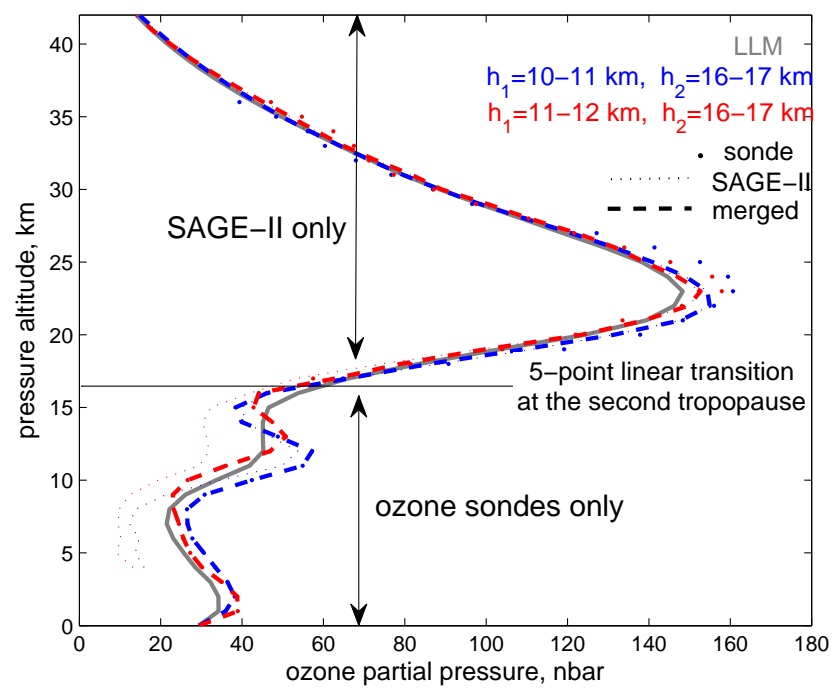

Fig. 7. Ozonesonde profiles, SAGE-II profiles and the merged ozone profiles for double tropopauses in February at latitudes $30^{\circ}-40^{\circ} \mathrm{N}$. Red and blue lines correspond to different doubletropopause heights. Dotted lines: SAGE-II climatological profiles, dots: ozonesonde profiles, dashed lines: merged $\mathrm{TpO}_{3}$ climatological profiles. The LLM climatological profile (grey solid line) is presented for reference.

from the merged profile to SAGE-II climatological profile is performed $(20-28 \mathrm{~km})$.

\subsubsection{Double tropopause}

Analogous to the processing of single-tropopause profiles, the statistics of ozone profiles in the case of a double 
tropopause is computed only for tropopause heights that are available both in ozonesonde and satellite data. This requirement results in characterization of ozone profiles for double tropopauses only for latitudes between $30^{\circ}$ and $40^{\circ} \mathrm{N}$ and only from January to March.

Due to reduced accuracy of SAGE-II measurements in the troposphere and relatively short vertical spacing between the tropopauses, any weighting of ozonesonde and SAGE-II data in this altitude range can induce non-realistic ozone profiles between the tropopauses. Since using SAGE-II data as low as possible improves the data representativeness and since the second tropopause is high, at altitudes $16-18 \mathrm{~km}$, we have decided to use a simple merging: sounding data are used up to the second tropopause with a five-point linear transition (corresponding to a $5 \mathrm{~km}$ layer) to SAGE-II data above this altitude. Data merging in the case of double tropopauses is illustrated in Fig. 7.

\section{Ozone morphology and comparisons}

The tropopause-height-related ozone climatology provides an additional dimension (further categorization by tropopause height) not available in traditional vertical ozone profile climatologies. Figure 8 shows examples of ozone profiles from the $\mathrm{TpO}_{3}$ for selected months and latitude zones. As expected, the main differences in profiles, which depend on tropopause height, are observed in the UTLS region. In the stratosphere, the profiles corresponding to different tropopause heights are close to each other, as shown earlier by Steinbrecht et al. (1998). The clear exception is in Antarctic spring $\left(60^{\circ}-70^{\circ} \mathrm{S}\right.$ in October), where ozone profiles through the entire stratosphere and UTLS are dramatically different for different tropopause heights. As explained in Sect. 1, ozone abundances and the tropopause height are inter-related under such conditions, because the location of the tropopause is influenced by the temperature in the lower stratosphere. Since the longitudinal structure of the ozone distribution is quasi-stationary over Antarctica in spring and strongly correlated with the tropopause height, the $\mathrm{TpO}_{3}$ climatology allows a partial characterization of longitudinal variability.

Substantial differences in ozone distributions in the Northern and Southern hemispheres are clearly apparent in Fig. 8.

As noted above, the stored information on the distribution of tropopause heights allows downgrading the $\mathrm{TpO}_{3}$ climatology to a standard sea-level-referenced climatology, for example, for comparison with previously created climatologies. For such a presentation, the monthly mean profiles $\rho_{\mathrm{m}}$ can be computed as the mathematical expectation, i.e., the weighted mean of the ozone profiles corresponding to different tropopause heights, $\rho_{i}$, with their respective probabilities $f_{i}$ :

$\rho_{\mathrm{m}}=\sum \rho_{i} \cdot f_{i}$.
Figure 9 shows profiles from the $\mathrm{TpO}_{3}$ climatology for several latitude zones and months, which are colored according to their probabilities (from dark blue for seldom occurring tropopauses to reddish for frequently occurring ones), and the monthly mean profiles $\rho_{\mathrm{m}}$ corresponding to a tropopauseinsensitive climatology, which are indicated by thick red lines. These monthly mean profiles, $\rho_{\mathrm{m}}$, are very close to the LLM climatological profiles (grey dashed lines): they are usually within $\pm 3 \%$ in the stratosphere, within $\pm 20 \%$ in the troposphere and can differ by up to $30-40 \%$ in the UTLS. Latitude zones and months were selected and arranged to highlight similarities, differences and the seasonal dependence of climatological ozone distributions in both hemispheres. In addition to features that are seen also in sea-levelreferenced climatologies (strong north-south differences in springtime ozone at high latitudes, latitude dependence of the ozone peak altitude, seasonal ozone variations), the $\mathrm{TpO}_{3}$ climatology supports a richer view of the ozone distribution and variability, especially in the UTLS. In particular, the range of tropopause heights, and thus the ozone variability in the UTLS, is generally larger in the Northern Hemisphere. This is a combined effect of a larger dynamical variability and better coverage by ozonesonde data as can be seen when Figs. 2 and 9 are compared. It is interesting that the inter-relation between the tropopause heights and ozone profiles in the whole stratosphere is observed not only at SH high latitudes in spring, but also over the $\mathrm{NH}$, thus suggesting the same mechanism for this inter-relation. As observed in Fig. 9, climatological profiles corresponding to a certain tropopause height can be significantly different from the monthly mean $\rho_{\mathrm{m}}$ (and from the sea-level-referenced climatology).

Figure 10 (left panel) shows the percentage difference in annual average ozone between $\rho_{\mathrm{m}}$ and the LLM climatology as a function of altitude and latitude. The right panel of Fig. 10 shows the same comparison but with the new climatology of McPeters and Labow (2012) (hereafter ML), which is an updated version of the LLM climatology with the number of atmospheric layers increased from 61 to 66, use of more ozonesonde data, and use of the MLS/Aura ozone data (2004-2010) instead of SAGE-II and MLS/UARS. In the middle stratosphere in the majority of locations, differences are very small (i.e., within $3 \%$, with respect to both climatologies). The largest relative differences between these climatologies are in the tropical troposphere and the UTLS. This is to be expected and can be explained by a larger number of ozonesonde stations used in the $\mathrm{TpO}_{3}$ climatology compared to both the LLM and ML climatologies (note that tropical ozone at lower altitudes has a pronounced zonal structure; e.g., Thompson et al., 2012; Tilmes et al., 2012). This hypothesis on the high sensitivity of the ozone climatology in the tropical troposphere to the amount of ozonesonde profiles used is confirmed also by a significant difference between the ML and LLM climatologies in this region (differences between the left and right panels in Fig. 10; see also Fig. 8 in McPeters and Labow, 2012). During this 


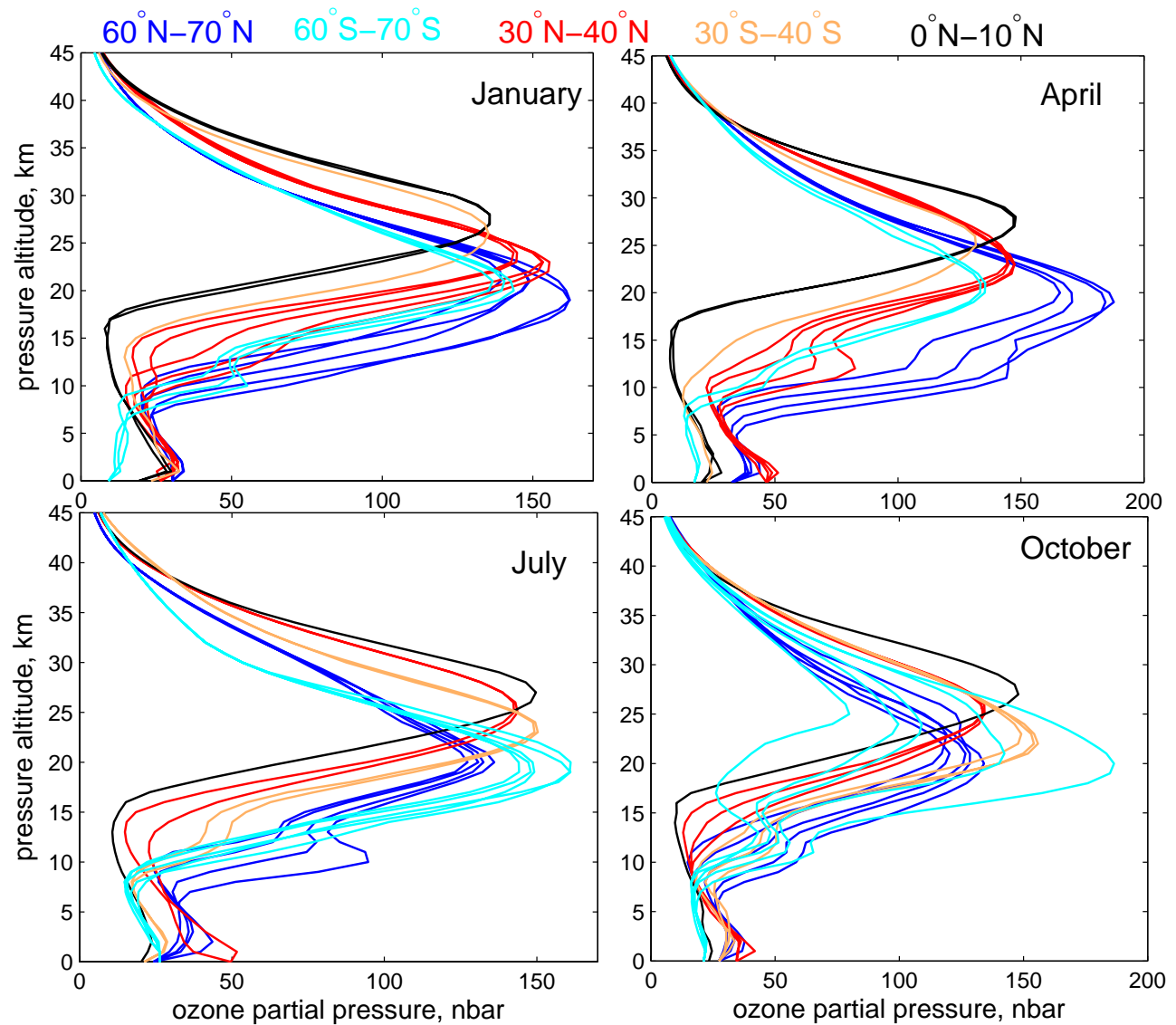

Fig. 8. Examples of ozone profiles in the linked ozone-tropopause climatology $\mathrm{TpO}_{3}$ for January, April, July and October, in different latitude zones indicated by different colors.

comparison, we found also that ozonesonde data from La Réunion station were used for different latitude zones in the discussed climatologies. In our climatology, La Réunion has coordinates of $21^{\circ} \mathrm{S}, 55^{\circ} \mathrm{E}$, and the data are included into the zone $20-30^{\circ} \mathrm{S}$, while the LLM climatology reports the coordinates $20^{\circ} \mathrm{S}, 55^{\circ} \mathrm{E}$ for La Réunion station and uses its data for the $10-20^{\circ} \mathrm{S}$ latitude zone; in the ML climatology, La Réunion data are used in both $10-20^{\circ} \mathrm{S}$ and $20-30^{\circ} \mathrm{S}$ latitude zones. A relatively large difference between $\rho_{\mathrm{m}}$ and the LLM climatology is observed also over Antarctica and results from a combined effect of a larger number of soundings and the tropopause-included representation. The corresponding difference with respect to the ML climatology is even larger due to the use of different satellite instruments; it is fully consistent with differences between the ML and LLM climatologies shown in McPeters and Labow (2012).

In general, standard deviations in the $\mathrm{TpO}_{3}$ climatology are as expected, being larger in winter at high and midlatitudes and smaller in summer (Fig. 11). The most important feature of $\mathrm{TpO}_{3}$ is reduced variability in the UTLS region compared to the LLM climatology in the majority of cases. As shown in Fig. 11, cases of larger/comparable variability correspond to tropopause heights with small probabil- ity of occurrence, and might therefore be indicative of a too small statistical sample. For frequently occurring tropopause heights, the reduction in standard deviation is $20-40 \%$ in the UTLS, compared to the LLM climatology.

The $\mathrm{TpO}_{3}$ climatology also can be easily downgraded to a tropopause-referenced climatology of monthly mean profiles. The weighted tropopause-referenced $\mathrm{TpO}_{3}$ variances

$\sigma_{\mathrm{m}}^{2}=\sum \tilde{\sigma}_{i}^{2} f_{i}$

then correspond to monthly variability of the tropopausereferenced climatology in the UTLS. In Eq. (4), $\tilde{\sigma}_{i}$ are the $\mathrm{TpO}_{3}$ climatological standard deviations corresponding to different tropopause heights in the tropopause-referenced representation and $f_{i}$ their respective probabilities. Figure 12 compares the values of $\sigma_{\mathrm{m}}$ in the UTLS with the standard deviations of the recently created advanced tropopausereferenced ozone profile climatology of Bak et al. (2013). As expected, the UTLS variabilities for the downgraded $\mathrm{TpO}_{3}$ climatology and the pure tropopause-referenced climatology are similar.

As described in detail above, the characterization of double tropopauses is performed only between $30^{\circ} \mathrm{N}$ and $40^{\circ} \mathrm{N}$ and for the months of January to March. For these 


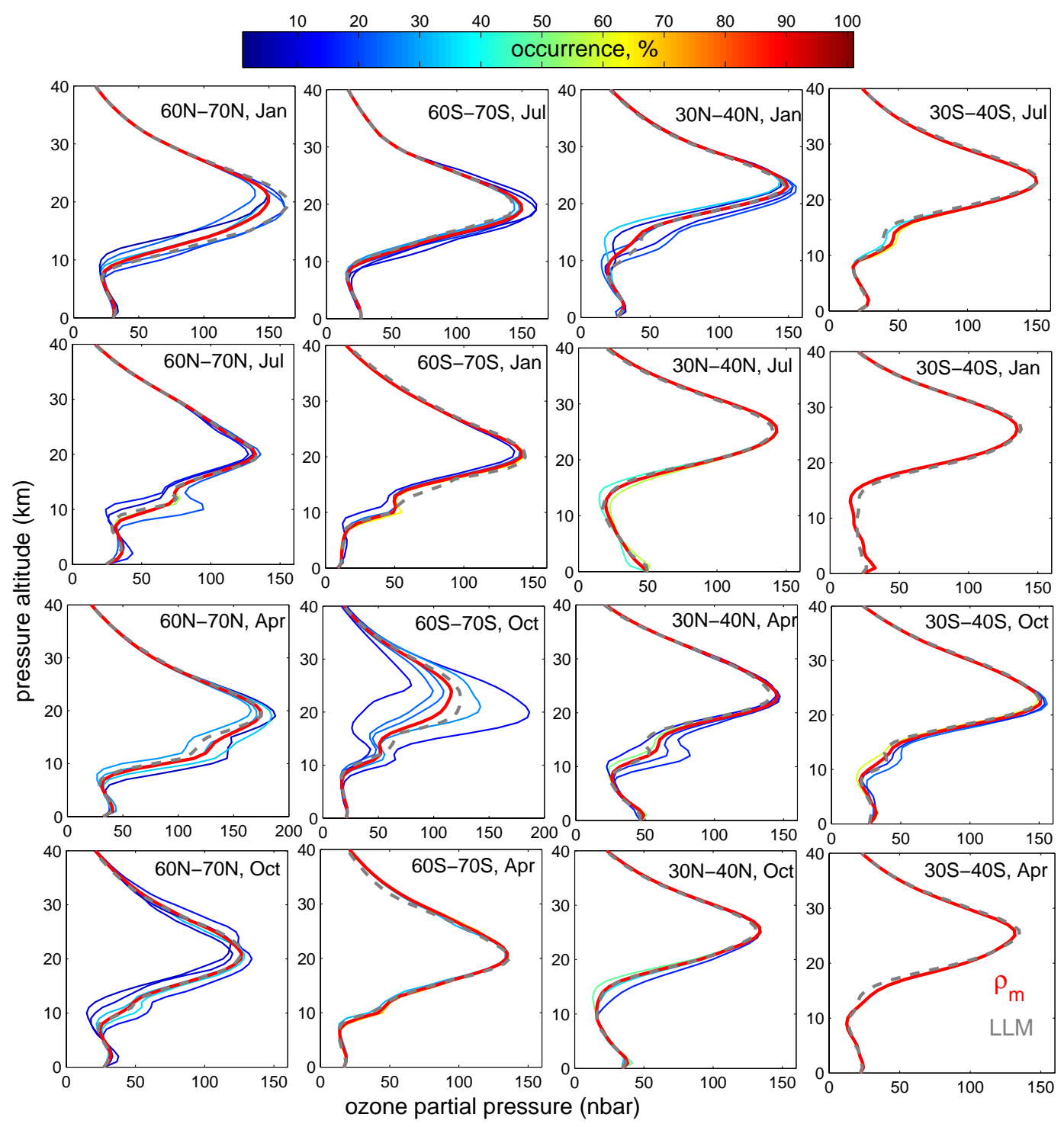

Fig. 9. Comparison of the $\mathrm{TpO}_{3}$ climatology with the LLM climatology, for selected latitude bands and months. Thin colored lines: profiles from $\mathrm{TpO}_{3}$ climatology; color indicates the probability distribution (frequency of occurrence) of the corresponding tropopause height. Red thick lines are the profiles.

months, ozone profiles corresponding to double-tropopause temperature profiles were compared with those corresponding to single tropopauses (Fig. 13). Double-tropopause profiles systematically exhibit reduced ozone concentrations in the lower stratosphere (altitudes $\sim 10-15 \mathrm{~km}$ ) compared to single-tropopause profiles having similar tropopause heights, in agreement with the findings of Randel et al. (2007). The profiles corresponding to single tropopauses in Fig. 13 show clearly the presence of two populations: one with high tropopauses at $15-16 \mathrm{~km}$ and lower stratospheric ozone (tropical air) and another with low tropopauses at 8$10 \mathrm{~km}$ and higher stratospheric ozone (mid-latitude air). The double-tropopause profiles appear to be a mixture of these two populations, with a transition from low-tropopause to high-tropopause profiles. This is a clear indication that occurrence of double tropopauses is associated with the transport of tropical air, in line with current understanding of the stratosphere-troposphere exchange (Gettelman et al., 2011).

\section{On using the joint ozone and tropopause height climatology in satellite retrievals}

To assess how the new ozone climatology affects vertical ozone profile retrievals from satellite-based instruments, the new climatology was tested using the operational ozone profile algorithm for the Ozone Monitoring Instrument (OMI) on board the NASA Earth Observing System (EOS) Aura 

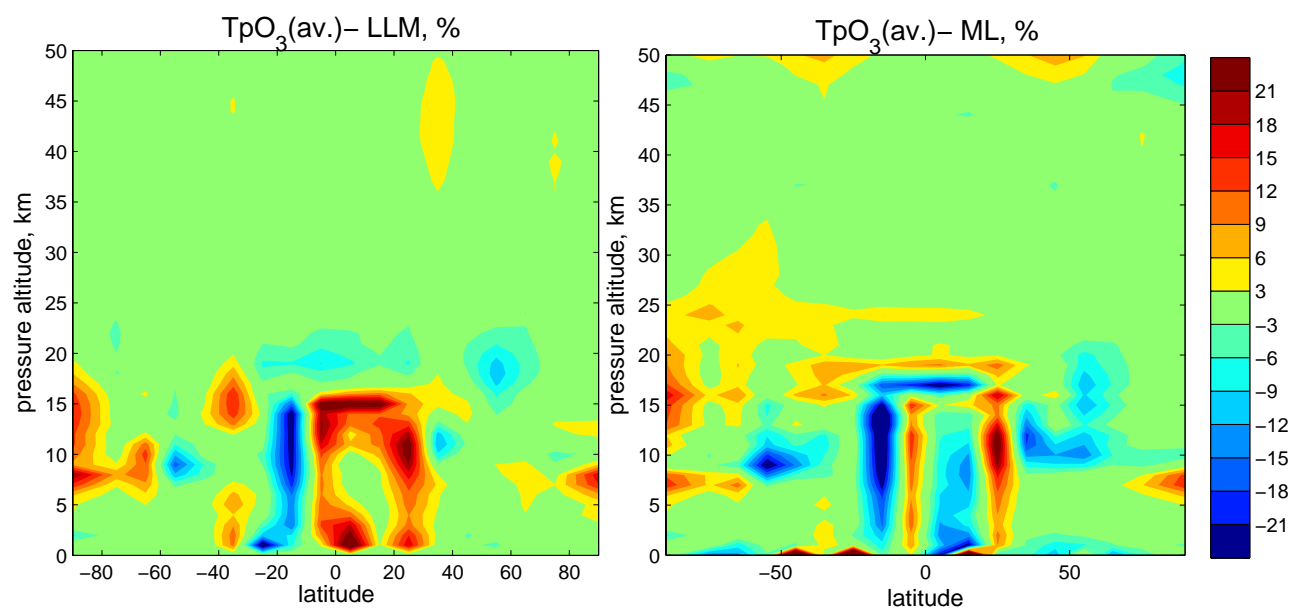

Fig. 10. Percent difference in annual ozone as a function of latitude and altitude between the downgraded (monthly average) $\mathrm{TpO}_{3}$ climatology and LLM (left) and ML (right) climatologies.

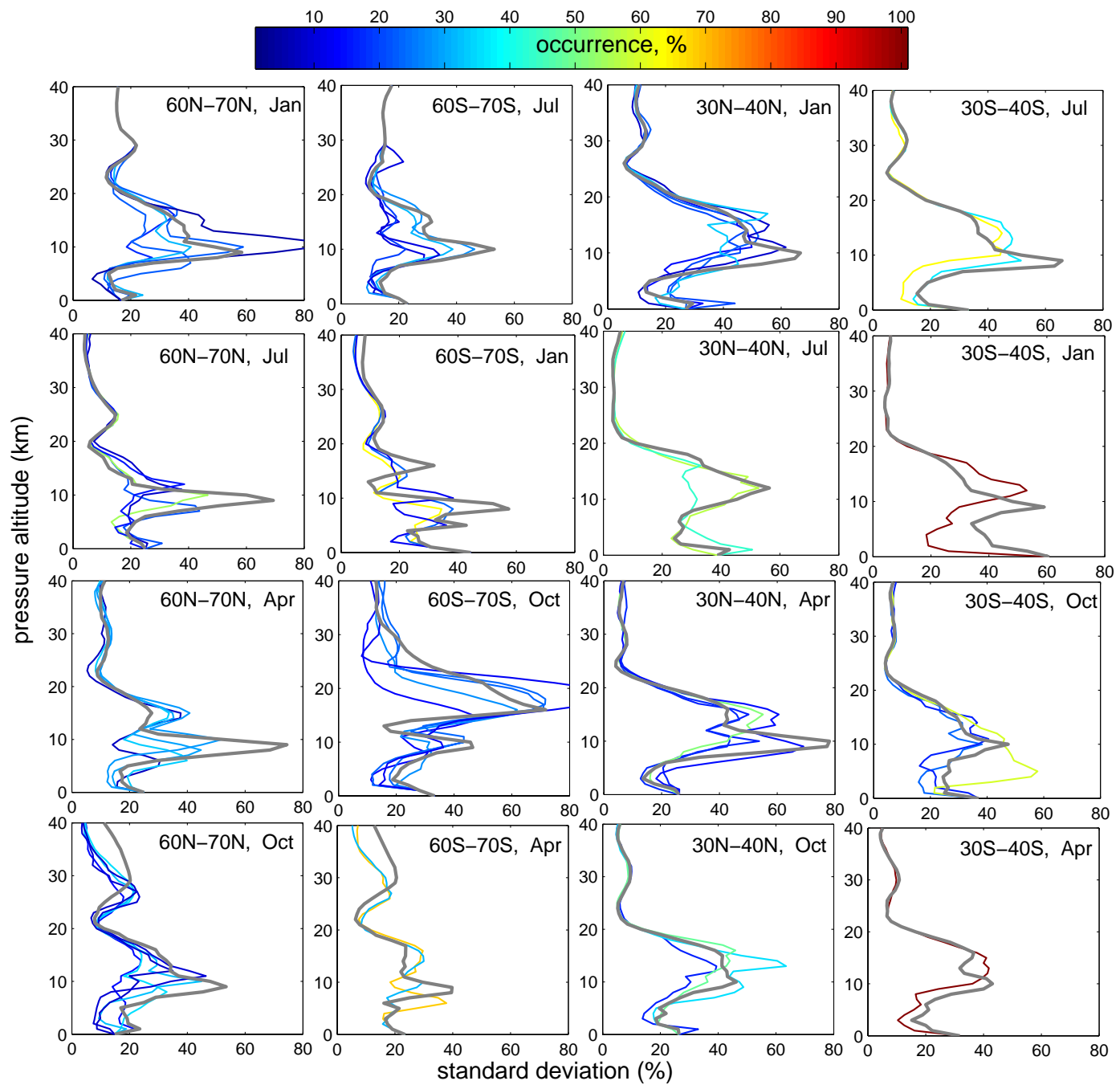

Fig. 11. As in Fig. 9 but for standard deviations. LLM variability is indicated by grey lines. 

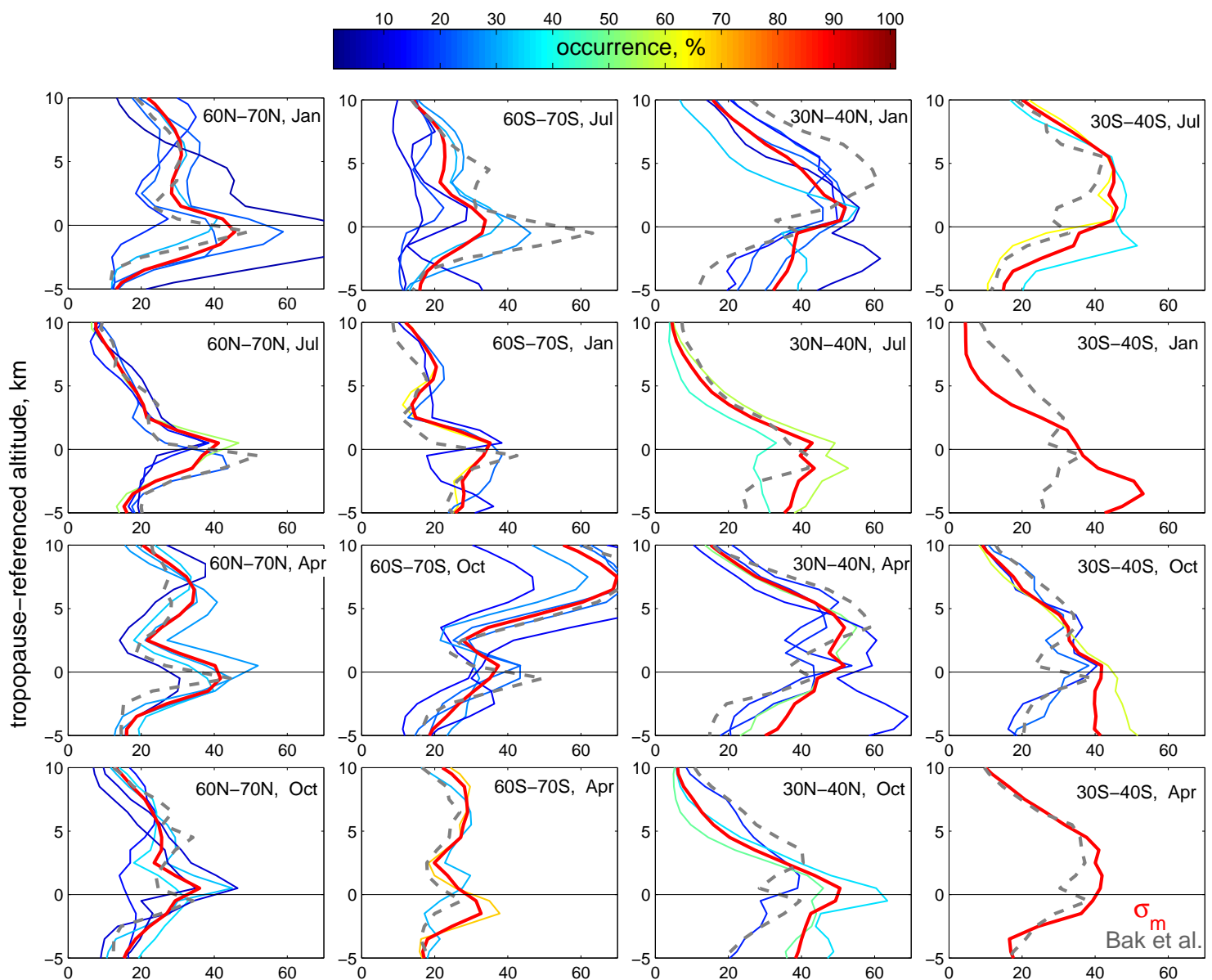

standard deviation, \%

Fig. 12. Variability in UTLS in the tropopause-referenced representation (zero is the tropopause height). Thin colored lines: standard deviation profiles from $\mathrm{TpO}_{3}$ climatology; color indicates the probability distribution (frequency of occurrence) of the corresponding tropopause height. Red thick lines are the profiles $\sigma_{\mathrm{m}}$ (Eq. 4) corresponding to the downgraded $\mathrm{TpO}_{3}$ climatology. Grey dashed lines show the standard deviations from the climatology by Bak et al. (2013). Latitude zones and months are indicated in the figure.
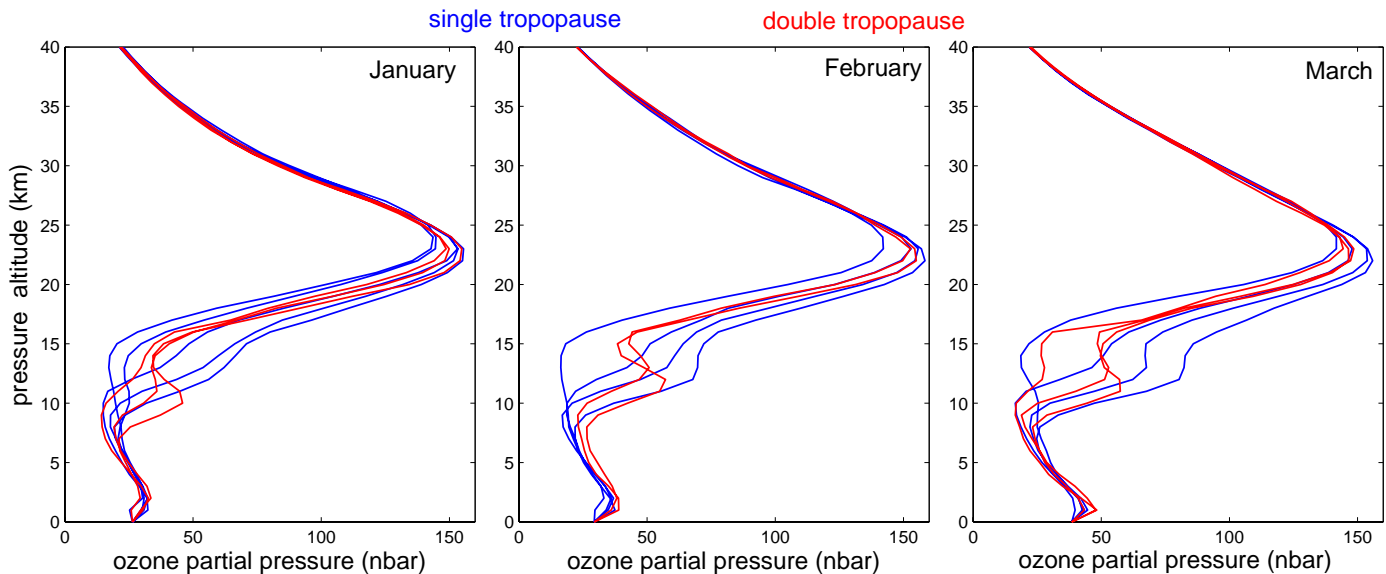

Fig. 13. $\mathrm{TpO}_{3}$ climatological ozone profiles at $30-40^{\circ} \mathrm{N}$ corresponding to double-tropopause (red lines) and single-tropopause (blue lines) temperature profiles. 

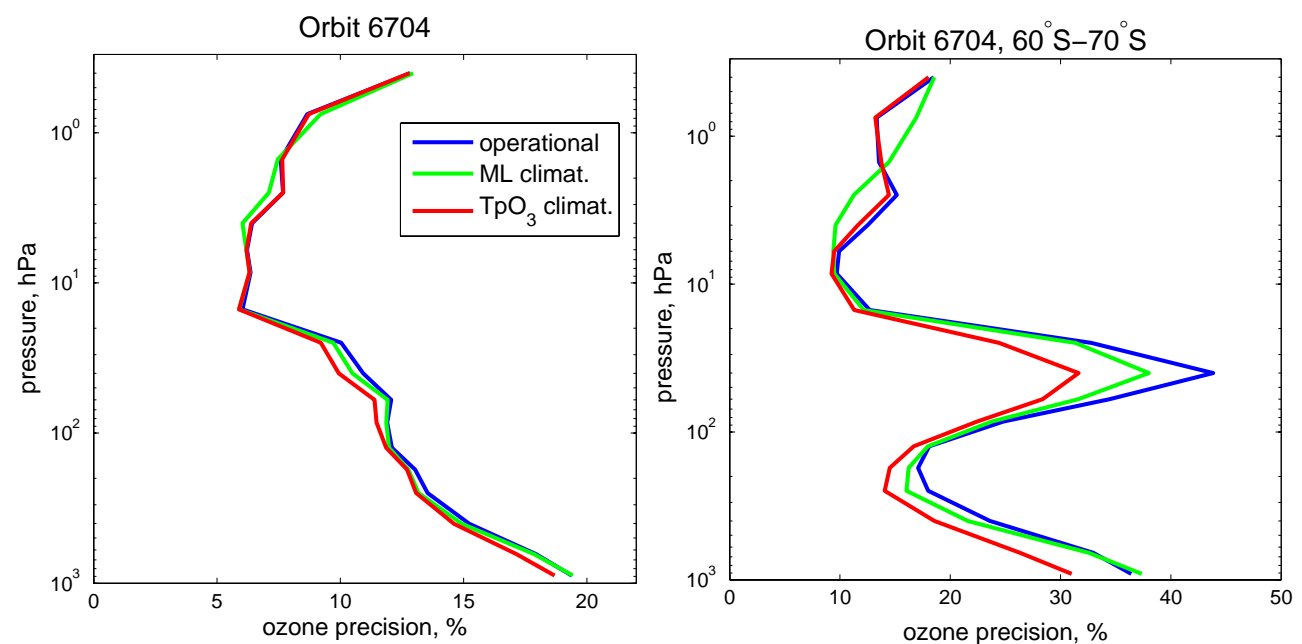

Fig. 14. The effect of a priori climatology on OMI ozone retrievals. Averaged ozone precision profiles for the whole orbit 6704 (left) and for latitudes $60-70^{\circ} \mathrm{S}$ on this orbit (right) with three different climatologies used in retrievals: operational (blue lines), ML climatology (green lines) and the created joint tropopause height and ozone climatology $\mathrm{TpO}_{3}$ (red).

satellite (Schoeberl et al., 2006). OMI, which has been making measurements since 2004, is a nadir-viewing, ultravioletvisible $(270-500 \mathrm{~nm})$ imaging spectrometer, which provides daily global coverage with high spatial and spectral resolution (Levelt et al., 2006a, b).

A detailed description of the OMI ozone profile algorithm (OMO3PR) is given in Kroon et al. (2011). Briefly, the retrieval is based on the strong decrease in the ozone absorption cross section between wavelengths of $270 \mathrm{~nm}$ and $330 \mathrm{~nm}$. The radiation at the longer wavelengths passes through the whole atmosphere while the shortest wavelengths are absorbed in higher layers of the atmosphere. Measuring the spectral changes as the radiation is absorbed in the atmosphere can be used to retrieve the vertical distribution of ozone. The retrieval algorithm uses optimal estimation (Rodgers, 2000), where the difference between the measured and modeled sun-normalized radiances is minimized by adjusting the amount of ozone in each atmospheric layer. This method requires a priori information on ozone profiles. The operational OMI ozone profile retrieval uses the LLM climatology.

The effects of the use of two alternative ozone climatologies on the OMI retrievals are examined. The first is the climatology of McPeters and Labow (2012) (ML climatology), and the second is the linked ozone and tropopause height $\left(\mathrm{TpO}_{3}\right)$ climatology detailed in earlier sections. To implement the $\mathrm{TpO}_{3}$ climatology, which includes information on the tropopause height, in the OMI retrievals, the OMO3PR algorithm has been modified. Tropopause height was calculated in the algorithm in a similar way to that presented in Sect. 3 above, using temperature profiles from ECMWF. Then a new dimension was added to the a priori ozone lookup table in the form of tropopause height. When an observed tropopause height is outside the range of climatolog- ical tropopause heights, the nearest climatological value is taken.

For the assessment, two orbits (6702 and 6704, 18 October 2005) were processed using the operational LLM climatology, ML climatology and $\mathrm{TpO}_{3}$ climatology. For saving processing time, only every 10 th measurement and only 10 pixels from the center of the swath were considered. As in the operational version, a priori variability of $20 \%$ was assumed for all latitudes and altitudes, except for ozone hole conditions (between August and December south of $50^{\circ} \mathrm{S}$ ) where the variability was $60 \%$ for altitudes between 21 and $50 \mathrm{~km}$ and $30 \%$ for all other altitudes. The correlation length of the off-diagonal elements of the a priori covariance matrix is $6 \mathrm{~km}$ in all tests.

Since the results are very similar for both orbits, only the results for orbit 6704 are presented. Figure 14 (left) shows the average precision of ozone profiles for the whole orbit. Here, precision refers to the estimated random uncertainty of the retrieved profiles provided by the statistical optimization procedure (Kroon et al., 2011, http://disc.sci.gsfc.nasa. gov/Aura/data-holdings/OMI/omo3pr_v003.shtml). The use of the ML climatology slightly improves the estimated ozone precision, with the improvement maximizing at higher altitudes. The $\mathrm{TpO}_{3}$ climatology improves the precision even more compared to operational and ML climatologies. As expected, the effect of using the $\mathrm{TpO}_{3}$ climatology maximizes between $60^{\circ} \mathrm{S}$ and $70^{\circ} \mathrm{S}$, where a nearly stationary springtime ozone zonal anomaly is observed, and the abundance of stratospheric ozone and the tropopause height are interrelated. As Fig. 14 (right) shows, the $\mathrm{TpO}_{3}$ climatology improves the accuracy of the retrieval by several percent in the troposphere and up to $10 \mathrm{hPa}$. At altitudes above $6 \mathrm{hPa}$, using the ML climatology provides the smallest precision values. Changes in a priori profiles result in changes in retrieved 


\begin{tabular}{|c|c|c|c|c|c|}
\hline \multicolumn{4}{|c|}{ Tropopause height (lower limit of 1-km bin): } & 16 & 17 \\
\hline \multicolumn{6}{|c|}{ Tropopause height frequency: 80.44419 .556} \\
\hline \multicolumn{6}{|c|}{ Ozone mixing ratio (ppmv) } \\
\hline $\mathrm{P}$ & z & $\mathrm{tp}=16 \mathrm{~km}$ & $\mathrm{tp}=17 \mathrm{~km}$ & & \\
\hline 1013.25 & 0 & 0.019 & 0.019 & & \\
\hline 877.44 & 1 & 0.032 & 0.034 & & \\
\hline 759.83 & 2 & 0.035 & 0.037 & & \\
\hline 657.99 & 3 & 0.036 & 0.040 & & \\
\hline 569.79 & 4 & 0.039 & 0.042 & & \\
\hline 493.42 & 5 & 0.041 & 0.044 & & \\
\hline 427.28 & 6 & 0.043 & 0.046 & & \\
\hline 370.01 & 7 & 0.046 & 0.047 & & \\
\hline 320.42 & 8 & 0.048 & 0.048 & & \\
\hline 277.47 & 9 & 0.047 & 0.048 & & \\
\hline 240.28 & 10 & 0.048 & 0.049 & & \\
\hline 208.07 & 11 & 0.051 & 0.052 & & \\
\hline 180.18 & 12 & 0.055 & 0.055 & & \\
\hline 156.03 & 13 & 0.059 & 0.061 & & \\
\hline 135.12 & 14 & 0.064 & 0.066 & & \\
\hline 117.01 & 15 & 0.075 & 0.074 & & \\
\hline 101.33 & 16 & 0.078 & 0.091 & & \\
\hline 87.74 & 17 & 0.114 & 0.109 & & \\
\hline 75.98 & 18 & 0.246 & 0.196 & & \\
\hline 65.80 & 19 & 0.504 & 0.399 & & \\
\hline 56.98 & 20 & 0.882 & 0.750 & & \\
\hline 49.34 & 21 & 1.352 & 1.215 & & \\
\hline
\end{tabular}

Fig. 15. An example of the records in the ASCII file for single-tropopause cases. The occurrence frequency (the probability distribution) of tropopause heights is presented in \%. After the ozone mixing ratio, values of the standard deviation are written in the file.

ozone profiles and their precision estimates (note that the relative a priori uncertainty was the same in all experiments). More realistic a priori profiles result in "more optimal" solutions found by the non-linear iterative optimization. We believe that this is the main reason for reduced precision in our tests. Detailed studies of the influence of a priori information on the ozone profiles retrieved from OMI, their validation with independent data sets, and the effect of using not only the profiles but also the variabilities of the new $\mathrm{TpO}_{3}$ climatology will be the subject of future work.

\section{Data availability}

The $\mathrm{TpO}_{3}$ climatology is provided in ASCII format (with README file) and can be found at http://igaco-o3.fmi.fi/ VDO/linked_climatology.html. It is included also as a supplement to this paper. The $\mathrm{TpO}_{3}$ climatology consists of folders corresponding to the $10^{\circ}$ latitude zones (self-explanatory names, e.g., "10N_20N"). Each folder includes 12 files corresponding to 12 months. For example, for January the file name is "01.dat" for single tropopauses and "01_double.dat" for double tropopauses (if present). The structure of each ASCII file for single tropopauses is presented in Fig. 15. The reported tropopause heights correspond to the lower limit of the $1 \mathrm{~km}$ interval. For example, the tropopause height of
$16 \mathrm{~km}$ is for a tropopause between 16 and $17 \mathrm{~km}$. The files contain the mean ozone profiles and their variability (standard deviation) in $\%$. The structure of the ASCII files for double tropopauses is illustrated by Fig. 16. It is very similar to that for single tropopauses.

\section{Discussion and summary}

This paper introduces a new tropopause-related ozone climatology in which ozone profiles are categorized according to the tropopause or double-tropopause heights. This climatology has several benefits compared to a sea-level- or tropopause-referenced climatology:

- The dependence of the ozone abundance and its variability on tropopause height is preserved. This allows a more accurate characterization of ozone profiles and a partial characterization of longitudinal variability.

- Variability in UTLS is reduced when compared to sealevel-referenced climatologies.

- Ozone profiles in the presence of double tropopauses are somewhat better characterized.

- The probability distribution of tropopause heights provides additional climatological information and allows 


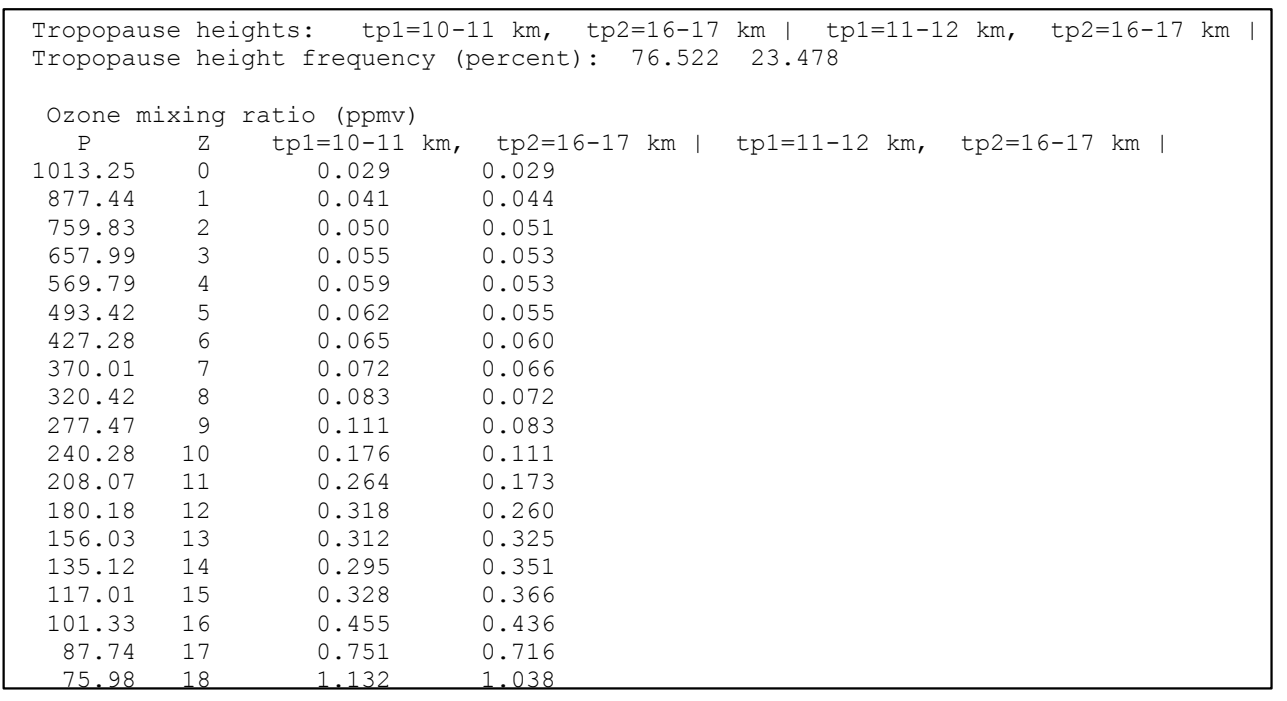

Fig. 16. An example of the records in the ASCII file for double-tropopause cases. "tp1" and "tp2" denote the first and the second tropopauses, respectively. After the ozone mixing ratio, values of the standard deviation are written in the file.

transforming/comparing the $\mathrm{TpO}_{3}$ climatology to a more traditional sea-level-referenced or tropopausereferenced climatology.

It is expected that the $\mathrm{TpO}_{3}$ climatology might be useful for ozone retrievals from satellite instruments that use a priori information about the vertical distribution of ozone. First tests on applying this climatology in ozone retrievals from OMI have shown pronounced reduction in uncertainty of retrieved ozone profiles in the UTLS region, up to $10 \%$ for some locations. In particular, the main advantages are observed where there is a significant correlation between stratospheric ozone and tropopause height (e.g., in spring over Antarctica), as expected.

For creating a tropopause-related ozone climatology, reliable profiles with sufficient vertical resolution from the ground to the mesosphere are needed. However, such data are not available from a single instrument. In the study described here, measurements from ozonesondes and SAGEII were used for the analysis. These data sets are characterized by a high vertical resolution, good data precision, and they are nearly unbiased with respect to each other. However, both data sets have limitations related to spatial and temporal coverage. The $\mathrm{TpO}_{3}$ climatology is therefore best suitable for satellite instruments measuring in daytime (OMI, its successor TROPOMI (Veefkind et al., 2012), SBUV, GOME-2, OMPS). Another limitation of the $\mathrm{TpO}_{3}$ climatology is that is does not represent the present-day conditions due to ozone trends. However, this seems to be not important for satellite retrieval algorithms, because the ozone trends (a few percent per decade, according to Kyrölä et al., 2013, Logan et al., 2012, and Staehelin et al., 2001) are much smaller than a priori ozone variability $(\sim 20 \%)$ used in retrievals.
Potential further (and future) extension/improvement of the $\mathrm{TpO}_{3}$ climatology would be the use of other high-vertical-resolution instruments (e.g., GOMOS/Envisat, HIRLDS/Aura, potentially future SAGE-III measurements on ISS). This extension can potentially adapt the ozonetropopause climatology to present-day conditions. However, this would require special care above $\sim 40 \mathrm{~km}$ due to diurnal variations of ozone, as well as the analysis of possible biases between the data sets.

\section{Supplementary material related to this article is

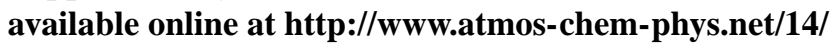 283/2014/acp-14-283-2014-supplement.zip.}

Acknowledgements. The work of V. F. Sofieva, J. Tamminen, and E. Kyrölä has been supported by Tekes and Ministry of Transport and Communications, Finland (project PP-TROPOMI), and the Academy of Finland (projects ASTREX and MIDAT). This study contributes also to the ESA/DRAGON-3 cooperation project. The authors sincerely thank J. Bak for comments and providing the tropopause-referenced climatology.

Edited by: M. Dameris

\section{References}

Añel, J. A., Antuña, J. C., de la Torre, L., Castanheira, J. M., and Gimeno, L.: Climatological features of global multiple tropopause events, J. Geophys. Res. Atmos., 113, D00B08, doi:10.1029/2007JD009697, 2008. 
Bak, J., Liu, X., Wei, J. C., Pan, L. L., Chance, K., and Kim, J. H.: Improvement of OMI ozone profile retrievals in the upper troposphere and lower stratosphere by the use of a tropopausebased ozone profile climatology, Atmos. Meas. Tech., 6, 22392254, doi:10.5194/amt-6-2239-2013, 2013.

Borsche, M., Kirchengast, G., and Foelsche, U.: Tropical tropopause climatology as observed with radio occultation measurements from CHAMP compared to ECMWF and NCEP analyses, Geophys. Res. Lett., 34, L03702, doi:10.1029/2006GL027918, 2007.

Evtushevsky, O. M., Grytsai, A. V, Klekociuk, A. R., and Milinevsky, G. P.: Total ozone and tropopause zonal asymmetry during the Antarctic spring, J. Geophys. Res., 113(D7), D00B06, doi:10.1029/2008JD009881, 2008.

Feng, S., Fu, Y., and Xiao, Q.: Trends in the global tropopause thickness revealed by radiosondes, Geophys. Res. Lett., 39, L20706, doi:10.1029/2012GL053460, 2012.

Fortuin, J. P. F. and Kelder, H.: An ozone climatology based on ozonesonde and satellite measurements, J. Geophys. Res., 103, 31709-31734, 1998

Gettelman, A., Hoor, P., Pan, L. L., Randel, W. J., Hegglin, M. I. and Birner, T.: The extratropical upper troposphere and lower stratosphere, Rev. Geophys., 49, RG3003, doi:10.1029/2011RG000355, 2011.

Grytsai, A., Grytsai, Z., Evtushevsky, A., Milinevsky, G., and Leonov, N.: Zonal wave numbers $1-5$ in planetary waves from the TOMS total ozone at 65S, Ann. Geophys., 23, 1565-1573, doi:10.5194/angeo-23-1565-2005, 2005.

Grytsai, A. V, Evtushevsky, O. M., Agapitov, O. V, Klekociuk, A. R., and Milinevsky, G. P.: Structure and long-term change in the zonal asymmetry in Antarctic total ozone during spring, Ann. Geophys., 25, 361-374, doi:10.5194/angeo-25-361-2007, 2007.

Hassler, B., Bodeker, G. E., and Dameris, M.: Technical Note: A new global database of trace gases and aerosols from multiple sources of high vertical resolution measurements, Atmos. Chem. Phys., 8, 5403-5421, doi:10.5194/acp-8-5403-2008, 2008.

Hoerling, M. P., Schaack, T. K., and Lenzen, A. J.: Global Objective Tropopause Analysis, Mon. Weather Rev., 119, 1816-1831, doi:10.1175/1520-0493(1991)119<1816:GOTA>2.0.CO;2, 1991.

Homeyer, C. R., Bowman, K. P., and Pan, L. L.: Extratropical tropopause transition layer characteristics from highresolution sounding data, J. Geophys. Res., 115, D13108, doi:10.1029/2009JD013664, 2010.

Hoor, P., Fischer, H., Lange, L., Lelieveld, J., and Brunner, D.: Seasonal variations of a mixing layer in the lowermost stratosphere as identified by the $\mathrm{CO}-\mathrm{O}_{3}$ correlation from in situ measurements, J. Geophys. Res. Atmos., 107, ACL 1-1-ACL 1-11, doi:10.1029/2000JD000289, 2002.

Ialongo, I., Sofieva, V., Kalakoski, N., Tamminen, J., and Kyrölä, E.: Ozone zonal asymmetry and planetary wave characterization during Antarctic spring, Atmos. Chem. Phys., 12, 2603-2614, doi:10.5194/acp-12-2603-2012, 2012.

Kroon, M., de Haan, J. F., Veefkind, J. P., Froidevaux, L., Wang, R., Kivi, R., and Hakkarainen, J. J.: Validation of operational ozone profiles from the Ozone Monitoring Instrument, J. Geophys. Res., 116, D18305, doi:10.1029/2010JD015100, 2011.

Kunz, A., Konopka, P., Müller, R., Pan, L. L., Schiller, C. and Rohrer, F.: High static stability in the mixing layer above the ex- tratropical tropopause, J. Geophys. Res. Atmos., 114, D16305, doi:10.1029/2009JD011840, 2009.

Kyrölä, E., Laine, M., Sofieva, V., Tamminen, J., Päivärinta, S.-M., Tukiainen, S., Zawodny, J., and Thomason, L.: Combined SAGE II-GOMOS ozone profile data set for 1984-2011 and trend analysis of the vertical distribution of ozone, Atmos. Chem. Phys., 13, 10645-10658, doi:10.5194/acp-13-10645-2013, 2013.

Levelt, P. F., Hilsenrath, E., Leppelmeier, G. W., Oord, G. H. J., Van Den, Bhartia, P. K., Tamminen, J., De Haan, J. F., and Veefkind, P.: Science Objectives Of The Ozone Monitoring Instrument, IEEE Trans. Geosci. Remote Sens., 44, 1199-1208, doi:10.1109/TGRS.2006.872336, 2006a.

Levelt, P. F., van den Oord, G. H. J., Dobver, M. R., Mälkki, A., Visser, H., de Vries, J., Stammes, P., Lundell, J. O. V., and Saari, H.: The ozone monitoring instrument, IEEE Trans. Geosci. Remote Sens., 44, 1093-1101, doi:10.1109/TGRS.2006.872333, 2006b.

Logan, J. A.: An analysis of ozonesonde data for the troposphere: Recommendations for testing 3-D models and development of a gridded climatology for tropospheric ozone, J. Geophys. Res. Atmos., 104, 16115-16149, doi:10.1029/1998JD100096, 1999.

Logan, J. A., Staehelin, J., Megretskaia, I. A., Cammas, J.-P., Thouret, V., Claude, H., De Backer, H., Steinbacher, M., Scheel, H.-E., Stübi, R., Fröhlich, M., and Derwent, R.: Changes in ozone over Europe: Analysis of ozone measurements from sondes, regular aircraft (MOZAIC) and alpine surface sites, J. Geophys. Res. Atmos., 117, D09301, doi:10.1029/2011JD016952, 2012.

McPeters, R. D. and Labow, G. J.: Climatology 2011: An MLS and sonde derived ozone climatology for satellite retrieval algorithms, J. Geophys. Res., 117(D10), D10303, doi:10.1029/2011JD017006, 2012.

McPeters, R. D., Labow, G. J., and Logan, J. A.: Ozone climatological profiles for satellite retrieval algorithms, J. Geophys. Res. 112, D05308, doi:10.1029/2005JD006823, 2007.

Pan, L. L., Randel, W. J., Gary, B. L., Mahoney, M. J., and Hintsa, E. J.: Definitions and sharpness of the extratropical tropopause: A trace gas perspective, J. Geophys. Res. Atmos., 109, D23103, doi:10.1029/2004JD004982, 2004.

Pan, L. L., Randel, W. J., Gille, J. C., Hall, W. D., Nardi, B., Massie, S., Yudin, V., Khosravi, R., Konopka, P., and Tarasick, D.: Tropospheric intrusions associated with the secondary tropopause, J. Geophys. Res. Atmos., 114, D10302, doi:10.1029/2008JD011374, 2009.

Peevey, T. R., Gille, J. C., Randall, C. E., and Kunz, A.: Investigation of double tropopause spatial and temporal global variability utilizing High Resolution Dynamics Limb Sounder temperature observations, J. Geophys. Res. Atmos., 117, D01105, doi:10.1029/2011JD016443, 2012.

Randel, W. J., Seidel, D. J., and Pan, L. L.: Observational characteristics of double tropopauses, J. Geophys. Res., 112, D07309, doi:10.1029/2006JD007904, 2007.

Randel, W. J., Wu, F., and Gaffen, D. J.: Interannual variability of the tropical tropopause derived from radiosonde data and NCEP reanalyses, J. Geophys. Res. Atmos., 105, 15509-15523, doi:10.1029/2000JD900155, 2000.

Reichler, T., Dameris, M., and Sausen, R.: Determining the tropopause height from gridded data, Geophys. Res. Lett., 30, 2042, doi:10.1029/2003GL018240, 2003. 
Rodgers, C. D.: Inverse Methods for Atmospheric sounding: Theory and Practice, World Scientific, Singapore, 2000.

Sakazaki, T., Fujiwara, M., Mitsuda, C., Imai, K., Manago, N., Naito, Y., Nakamura, T., Akiyoshi, H., Kinnison, D., Sano, T., Suzuki, M., and Shiotani, M.: Diurnal ozone variations in the stratosphere revealed in observations from the Superconducting Submillimeter-Wave Limb-Emission Sounder (SMILES) on board the International Space Station (ISS), J. Geophys. Res. Atmos., 118, 2991-3006, doi:10.1002/jgrd.50220, 2013.

Schoeberl, M. R., Douglass, A. R., Hilsenrath, E., Bhartia, P. K., Beer, R., Waters, J. W., Gunson, M. R., Froidevaux, L., Gille, J. C., Barnett, J. J., Levelt, P. F., and DeCola, P.: Overview of the EOS aura mission, Geosci. Remote Sensing, IEEE Trans., 44, 1066-1074, doi:10.1109/TGRS.2005.861950, 2006.

Staehelin, J., Harris, N. R. P., Appenzeller, C., and Eberhard, J.: Ozone trends: A review, Rev. Geophys., 39, 231-290, doi:10.1029/1999RG000059, 2001.

Steinbrecht, W., Claude, H., Köhler, U., and Hoinka, K. P.: Correlations between tropopause height and total ozone: Implications for long-term changes, J. Geophys. Res., 103, 19183-19192, doi:10.1029/98JD01929, 1998.

Thompson, A. M., Miller, S. K., Tilmes, S., Kollonige, D. W., Witte, J. C., Oltmans, S. J., Johnson, B. J., Fujiwara, M., Schmidlin, F. J., Coetzee, G. J. R., Komala, N., Maata, M., bt Mohamad, M., Nguyo, J., Mutai, C., Ogino, S.-Y., Da Silva, F. R., Leme, N. M. P., Posny, F., Scheele, R., Selkirk, H. B., Shiotani, M., Stübi, R., Levrat, G., Calpini, B., Thouret, V., Tsuruta, H., Canossa, J. V., Vömel, H., Yonemura, S., Diaz, J. A., Tan Thanh, N. T. and Thuy Ha, H. T.: Southern Hemisphere Additional Ozonesondes (SHADOZ) ozone climatology (2005-2009): Tropospheric and tropical tropopause layer (TTL) profiles with comparisons to OMI-based ozone products, J. Geophys. Res. Atmos., 117, D23301, doi:10.1029/2011JD016911, 2012.

Thouret, V., Cammas, J.-P., Sauvage, B., Athier, G., Zbinden, R., Nédélec, P., Simon, P., and Karcher, F.: Tropopause referenced ozone climatology and inter-annual variability (1994-2003) from the MOZAIC programme, Atmos. Chem. Phys., 6, 1033-1051, doi:10.5194/acp-6-1033-2006, 2006.

Tilmes, S., Lamarque, J.-F., Emmons, L. K., Conley, A., Schultz, M. G., Saunois, M., Thouret, V., Thompson, A. M., Oltmans, S. J., Johnson, B., and Tarasick, D.: Technical Note: Ozonesonde climatology between 1995 and 2011: description, evaluation and applications, Atmos. Chem. Phys., 12, 74757497, doi:10.5194/acp-12-7475-2012, 2012.
Tilmes, S., Pan, L. L., Hoor, P., Atlas, E., Avery, M. A., Campos, T., Christensen, L. E., Diskin, G. S., Gao, R.-S., Herman, R. L., Hintsa, E. J., Loewenstein, M., Lopez, J., Paige, M. E., Pittman, J. V, Podolske, J. R., Proffitt, M. R., Sachse, G. W., Schiller, C., Schlager, H., Smith, J., Spelten, N., Webster, C., Weinheimer, A., and Zondlo, M. A.: An aircraft-based upper troposphere lower stratosphere $\mathrm{O}_{3}, \mathrm{CO}$, and $\mathrm{H}_{2} \mathrm{O}$ climatology for the Northern Hemisphere, J. Geophys. Res. Atmos., 115, D14303, doi:10.1029/2009JD012731, 2010.

Veefkind, J. P., Aben, I., McMullan, K., Förster, H., de Vries, J., Otter, G., Claas, J., Eskes, H. J., de Haan, J. F., Kleipool, Q., van Weele, M., Hasekamp, O., Hoogeveen, R., Landgraf, J., Snel, R., Tol, P., Ingmann, P., Voors, R., Kruizinga, B., Vink, R., Visser, H., and Levelt, P. F.: TROPOMI on the ESA Sentinel-5 Precursor: A GMES mission for global observations of the atmospheric composition for climate, air quality and ozone layer applications, Remote Sens. Environ., 120, 70-83, doi:10.1016/j.rse.2011.09.027, 2012.

Wang, H. J., Cunnold, D. M., and Bao, X.: A critical analysis of Stratospheric Aerosol and Gas Experiment ozone trends, J. Geophys. Res. Atmos., 101, 12495-12514, doi:10.1029/96JD00581, 1996.

Wang, H. J., Cunnold, D. M., Thomason, L. W., Zawodny, J. M., and Bodeker, G. E.: Assessment of SAGE version 6.1 ozone data quality, J. Geophys. Res. Atmos., 107, ACH 8-1-ACH 818, doi:10.1029/2002JD002418, 2002.

Wang, P.-H., Cunnold, D. M., Trepte, C. R., Wang, H. J., Jing, P., Fishman, J., Brackett, V. G., Zawodney, J. M., and Bodeker, G. E.: Ozone variability in the midlatitude upper troposphere and lower stratosphere diagnosed from a monthly SAGE II climatology relative to the tropopause, J. Geophys. Res., 111(D21), D21304, doi:10.1029/2005JD006108, 2006.

Wei, J. C., Pan, L. L., Maddy, E., Pittman, J. V, Divarkarla, M., Xiong, X., and Barnet, C.: Ozone Profile Retrieval from an Advanced Infrared Sounder: Experiments with Tropopause-Based Climatology and Optimal Estimation Approach, J. Atmos. Ocean. Technol., 27, 1123-1139, doi:10.1175/2010JTECHA1384.1, 2010.

WMO: Meteorology - A three-dimensional science: Second session of the Commission for Aerology, WMO Bull., IV, 134-138, 1957. 